\title{
Animal sexual abuse - a reality in Portugal and Spain
}

\author{
Mariana Monteiro Campos Castanheira \\ Doctor of Veterinary Medicine, Universidade de Trás-os-montes e Alto Douro, Portugal \\ Master in Animal Law and Society, Universidad Autónoma de Barcelona, Spain \\ Cat House Manager and Fundraiser, Suara Foundation, Barcelona, Spain
}

Received: September 2019

Accepted: October 2019

\begin{abstract}
Recommended citation. MONTEIRO CAMPOS CASTANHEIRA, M., Animal sexual abuse - a reality in Portugal and Spain, dA. Derecho Animal (Forum of Animal Law Studies) 10/4 (2019) - DOI https://doi.org/10.5565/rev/da.455
\end{abstract}

\begin{abstract}
The sexual abuse of animals has persisted prehistoric times and is currently studied in the disciplines of history, medicine, psychiatry, veterinary medicine and law. The Portuguese legislation has no explicit reference to sexual contact with animals and the Spanish legislation had recently added "sexual exploitation of animals" which could be interpreted as implying the element of profit. The principal aim of this thesis is to prove that cases of animal sexual abuse in Portugal and Spain are not so infrequent as we may believe. We aim to establish the incidence and frequency of cases of sexual abuse detected by veterinarians in Portugal and Spain and to show that people are actively searching for zoophilic content online in these two countries. An online survey was made and directed to Spanish and Portuguese veterinarians. Our results left no doubt about the existence of such abuses in Portugal and Spain $(8.2 \%$ of veterinarians in our study had encountered or at least suspected of cases of sexual abuse). Moreover, our analyses via Google Trends proved that people are currently looking for zoophilic content online. With that said, we hope to authenticate the urgent need to change legislation to protect the victims of these abuses and to encourage other investigators to focus on this neglected subject.
\end{abstract}

Keywords: Sexual abuse of animals; Zoophilia; Animal pornography.

Resumen - El abuso sexual de animales - una realidad en Portugal y España

El abuso sexual de animales ha persistido en tiempos prehistóricos y actualmente se estudia en las disciplinas de historia, medicina, psiquiatría, medicina veterinaria y derecho. La legislación portuguesa no hace referencia explícita al contacto sexual con los animales y la legislación española ha añadido recientemente la "explotación sexual" de los animales, que podría interpretarse como un elemento de beneficio. El objetivo principal de este trabajo es probar que los casos de abuso sexual de animales en Portugal y España no son tan infrecuentes como podemos creer. Nuestro objetivo es establecer la incidencia y frecuencia de casos de abuso sexual detectados por veterinarios en Portugal y España y demostrar que las personas buscan activamente contenidos zoofílicos online en estos dos países. Se realizó una encuesta online dirigida a veterinarios españoles y portugueses. Nuestros resultados no dejaron dudas sobre la existencia de estos abusos en Portugal y España (el 8,2\% de los veterinarios en nuestro estudio habían encontrado o por lo menos sospechaban de casos de abuso sexual). Por otra parte, nuestros análisis a través de Google Trends demostraron que la gente está buscando contenido online zoofílico. Dicho esto, esperamos demostrar la urgente necesidad de cambiar la legislación para proteger a las víctimas de estos abusos y animar a otros investigadores a centrarse en este tema poco estudiado.

Palabras clave: Abuso sexual de animales; Zoofilia; Pornografía animal. 
Table of contents

$\begin{aligned} \text { I. } & \text { INTRODUCTION } \\ \text { II. } & \text { LITERATURE REVIEW } \\ \text { III. } & \text { OBJECTIVES } \\ \text { IV. } & \text { METHODS AND MATERIAL } \\ \text { V. } & \text { RESULTS AND DISCUSSION } \\ \text { VI. } & \text { FINAL CONSIDERATIONS } \\ \text { VII. } & \text { REFERENCES }\end{aligned}$

APENDIX 1 - Online survey: Spanish version

\section{I - INTRODUCTION}

Animal sexual abuse, zoophilia, bestiality (or any other name for the act of a human having sexual contact with an non-human animal) is a colossal taboo in our society. However, the existence of these inhumane acts is undeniable. To illustrate, we hear about zoophilic acts in the news, we listen to jokes about them and we have easy online access to zoophilic images and videos.

Over the past few years, many studies have been published on child abuse as well as guidelines to help professionals on this sensitive topic. By contrast, very few have been published on animal sexual abuse. It is actually quite concerning how little investigation has been done on a subject that has lived through our history and culture since prehistoric times. The sexual abuse of animals is a difficult subject even for veterinarians, who more frequently face cases of animal mistreatment and negligence.

Humans have always utilised animals for different purposes. We insist on treating them as our property and to exploit them for our own needs. We use them for food, for clothing, for experimentation, for our entertainment and for countless other things. In this paper we will focus on their use for pleasure, more specifically for sexual pleasure.

We hope this paper will promote awareness and propel this alarming problem into discussion. We also wish to break the silence in the veterinary field and encourage more researchers to focus on this subject. We strongly believe this is an area where several disciplines of animal ethics, animal behaviour, anthrozoology, psychology, mental health, sociology and law need to collaborate.

This paper sets out to unveil the reality of animal sexual abuse in Portugal and Spain. We reviewed some of the literature on this subject as well as the studies that attempted to understand the roots of this human behaviour. Furthermore, we focused on the veterinarian's role and their importance to detect this kind of abuse, as they are the only professionals equipped with skills to detect injuries associated with this kind of abuse.

As the main goal of our work was to prove animal abuse is not so uncommon in Portugal and Spain, and to break this taboo, we used two different investigation approaches: a questionnaire directed to Spanish and Portuguese veterinarians with the intention of detecting if there have been cases of sexual abuse during the past few years and an analysis of the internet searches related to animal sexual abuse in Portugal and Spain.

\section{II - LITERATURE REVIEW}

\section{What is Zoophilia?}

Authors from distinct areas, such as criminology, psychiatry, veterinary medicine, etc., define sexual contact between humans and animals differently. The most common used words to describe sexual relation with animals are zoophilia and bestiality. In the historical literature the most common word is bestiality ${ }^{I}$. On the other hand, zoophilia is the term most ordinarily utilised by clinicians to refer to the erotic attraction to animals or the sexual contact with animals. The word "zoophilia" originates from two Greek words zoion (animal) and philos (friend, love). Thus, the person who engages in sex with animals is called zoophile or $z o o^{2}$. Yet distinctive terms and definitions have been used in the literature when alluding to sexual relations amongst animals and humans. To give an example, Masters (1966) defines zoophilia as "a paraphilia of the

\footnotetext{
${ }^{1}$ MILETSKI, H. Understanding Bestiality and Zoophilia. East West Publishing, LLC. (Bethesda 2002).

${ }^{2}$ BEETZ, A. Love, Violence and Sexuality in Relationships between Humans and Animals. Doctoral dissertation. (Germany 2002) 
stigmatic/eligibilic type, in which sexuoerotic arousal and facilitation or attainment of orgasm are responsive to and dependent upon engaging in cross-species sexual activities..."3. Later, Beirne, in 1997, proposes the term interspecies sexual assault, as it is less anthropocentric then the common term bestiality ${ }^{4}$.

According to some zoophiles, the difference between zoophilia and bestiality is zoophilia includes an emotional relation with the animal and bestiality just involves a sexual contact ${ }^{5}$. Miletski (2002) recommends using the term zoophilia when referring to emotional attachment to animals, preference for them as sexual partners or any sexual attraction towards animals. On the other hand, the term bestiality should only be used when describing a sexual contact between humans and animals ${ }^{7}$.

Munro 2006, propounds the view that the term zoophilia focuses on the human abuser instead of focusing on the animal, the one that suffers harm. For that reason, the author believes the term "animal sexual abuse" is more appropriated ${ }^{8}$.

Due to the existence of different terms to describe sexual contact with animals and their vagueness, recently, in 2011, Agrawall proposed a new classification of zoophilia, dividing it in 10 different classes: Class I Zoosexuals: human-animal role players - this class includes all the individuals that get excited with the though of having sex with animals but they do not use animals for sex, they rather ask their humanpartners to act like animals during sex. Class II zoosexuals: romantic zoophiles -individuals who keep animals as pets to get psychosexual stimulation but don't have sex with them. Class III zoosexuals: people having a zoophilic fantasy - zoophilic fantasizers - these people fantasize about having sexual contact with animals but don't actually do it. However, they may masturbate in the presence of the animal. Class IV zoosexuals: tactile zoophiles - those who get sexually excited by touching, stroking or fondling an animal or his/her genital parts. Some of them also rub their genitals on the animals. Class V zoosexuals: people having a fetishistic zoophilia - fetishistic zoophiles - individuals who use parts of animals, like fur, to excite them. Class VI zoosexuals: sadistic Bestials - individuals that torture animals for sexual pleasure. Class VII zoosexuals: Opportunistic zoosexuals - people that normally wouldn't have sex with animals but if no one is around and they have the opportunity, they do it. Generally, individuals on this class don't love animals at an emotional level. Class VIII zoosexuals: regular zoosexuals - people who have sex with both animals and humans but prefer animals. These individuals tend to love animals and do not want to hurt them. Class IX zoosexuals: homicidal bestials - individuals who kill animals in order to have sexual pleasure. Although they can have sexual intercourse with live animals, they prefer with the dead animal body after killing the animal. Class $X$ zoosexuals: exclusive zoosexuals - this class includes humans who have sexual relations exclusively with animals ${ }^{9}$.

\subsection{Different forms of sexual contact with animals}

There is a huge range of described sexual activities between humans and animals. Such activities include oral contact (mouth kissing or oral-genital contact), anal and vaginal penetration of the animal by humans and vice-versa ${ }^{10}$. They may also include exhibitionism (exposing genitals to animals), frotteurism (rubbing the genitals on the animal) and voyeurism (for example to look trough windows to watch dogs) ${ }^{11}$.

Massen (1994) distinguishes nine basic forms of zoophilia: 1 - incidental experience and latent zoophilia; 2 - zoophilic voyeurism (also called mixoscopic zoophilia); 3 -frottage (physical contact as a source of pleasure); 4 - the animal as a tool for masturbatory activities; 5 - the animal as a surrogate object for a behavioral fetishism (sadomasochistic practices, sexual murder, etc.); 6 - the animal as fetish; 7 physical contact and affection; 8 - the animal as a surrogate for a human sex partner; 9 - the animal as deliberately and voluntarily chosen sex partner ${ }^{12}$.

\section{History of Zoophilia - from prehistoric times to nowadays}

Bestiality has been prevalent in all cultures and continents since the dawn of history. Besides the fact

\footnotetext{
${ }^{3}$ MASTERS, R. E. L.. Sex-driven people. Sherbourne Press, Inc (Los Angeles 1966).

${ }^{4}$ BEIRNE, P. Rethinking bestiality: Towards a concept of interspecies sexual assault. Theoretical Criminology 1/3 (1997) 317-340.

${ }^{5}$ BEETZ, A. Love, Violence and Sexuality in Relationships between Humans and Animals. Doctoral dissertation. (Germany 2002).

${ }^{6}$ MILETSKI, H.. Understanding Bestiality and Zoophilia. East West Publishing, LLC. (Bethesda 2002).

${ }^{7}$ MILETSKI, H. Understanding Bestiality and Zoophilia. East West Publishing, LLC. (Bethesda 2002)

${ }^{8}$ MUNRO, H. Animal sexual abuse: a veterinary taboo? The Veterinary Journal 172 (2006) 195-197.

${ }^{9}$ AGGRAWAL, A. A new classification of zoophilia. Journal of Forensic and Legal Medicine 18 (2011) 73-78.

${ }^{10}$ BEETZ, A. Love, Violence and Sexuality in Relationships between Humans and Animals. Shaker Verlag(Germany 2002)

${ }^{11}$ MCNALLY R. J., LUCKASH B. M. Behavioral treatment of zoophilic exhibitionism. 281-4.

${ }^{12}$ MASSEN, J. Zoophilie. Die sexuelle Liebe zu Tieren. Pinto Press. (Köln 1994).
} 
this kind of practice has been punished in several cultures, it has persisted through time in art, literature and sexual behaviours ${ }^{13}$. There are records of these practices since mankind were cave dwellers. Waine (1968) believes our ancestors frequently had sexual relations with animals, based on discovered cave drawings ${ }^{14}$.

In ancient Egypt, many sexual activities were also recorded. For instance, some members of royalty had the reputation of participating in such acts ${ }^{15}$. Ancient Romans had bestiality shows at the Coliseum where animals raped women and sometimes men. There are also records of roman women training snakes to use them to masturbate ${ }^{16}$. Sexual intercourse with animals on stage was also common in ancient Greece and bestiality was frequent in Greek mythology ${ }^{17}$. For example, there is a myth regarding the wife of Minos (the king of Crete) who fell in love with a bull and in order to have sex with him disguised herself as a cow ${ }^{18}$.

Even in the Middle Ages some people believed that sexual relations with animals were healthy and could even cure some diseases ${ }^{19}$. To give you an illustration, bestiality is represented in Khajuraho temples, in India (see Figure 1) ${ }^{20}$. However, at the beginning of the $8^{\text {th }}$ century, in Spain, it was decided to give 20 years penance for those who committed bestiality ${ }^{21}$. At this time, what people most feared was that a sexual relation with an animal would result in a child that was half-human, half-animal with a demon like appearance $^{22}$. For this reason, at the end of Middle Ages bestiality was greatly persecuted ${ }^{23}$. Even in the sacred books, the Torah, the Bible, the Psalms and the Quran, we can find the presence of zoophilic acts ${ }^{24}$.

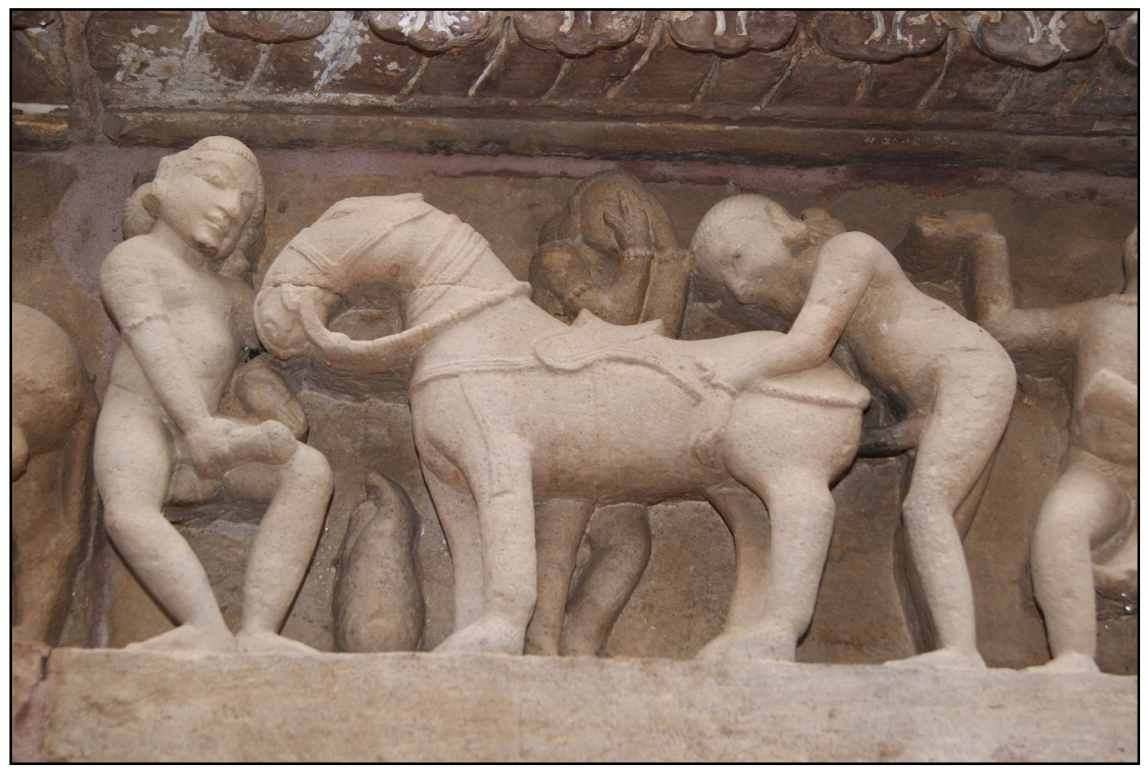

Figure 1 - Khajuraho Temple detail representing bestiality (RABE, 1996).

Despite the fact that it has always been a reality from past to present, zoophilia is still a taboo in our society. Unlike other sexual practices, zoophilia is not discussed on social media ${ }^{25}$. Nonetheless, occasionally news about animal sexual abuse is posted on social media around the world, showing that this kind of abuse still happens today. For example, a woman in South Carolina was accused of having sex with her pet dog and recording $i^{26}$. In London, 2016, a doctor was found guilty of possessing footage of

\footnotetext{
${ }^{13}$ MILETSKI, H. A history of bestiality. In Bestiality and Zoophilia - Sexual Relations with Animals. Purdue University Press (Indiana 2005) 1-22.

${ }^{14}$ WAINE, W. W. Canine Sexualis. CA: Publisher's Export. (San Diego 1968).

15 MILETSKI, H. A history of bestiality. In Bestiality and Zoophilia - Sexual Relations with Animals. Purdue University Press (Indiana 2005) 1-22.

${ }^{16}$ DEKKERS, M. Dearest Pet: On Bestiality. 2nd ed. (New York 1994).

${ }^{17}$ MASTERS, R. E. L. Sex-Driven People. Sherbourne Press (Los Angeles 1966)..

${ }^{18}$ Ibid.

${ }^{19}$ ROSENBERGER, J. R. Bestiality. Medco Books (Los Angeles 1968).

${ }^{20}$ RABE, M. Sexual Imagery on the "Phantasmagorical Castles" at Khajuraho. Journal of International Studies of Tantric Studies. 2 (1996) 1

${ }^{21}$ SALISBURY, J. E. The Beast Within-Animals in the Middle Ages. (New York 1994)

${ }^{22}$ MONTCLAIR, R. Tails of bestiality. Black Book Magazine (1997).

${ }^{23}$ DEKKERS, M. Dearest Pet: On Bestiality. 2nd ed. (New York 1994).

${ }^{24}$ YAŞAR, A., YIĞIT, A. Zoophilia: An evaluation from perspective the holy religions, legislation and ethics. Eurasian Journal of Veterinary Sciences. 32/2 (2016) 114-119.

${ }^{25}$ MASSEN, J. Zoophilie. Die sexuelle Liebe zu Tieren. Pinto Press (Köln 1994).

${ }^{26}$ WELLMAN, A. Woman 'filmed herself having sex with a sausage dog and then sent sick video to a pal'. Mirror. (2016) Retrieved from: http://www.mirror.co.uk/news/world-news/woman-filmed-herself-having-sex-7632818 
zoophilia, including a video of a man having sex with a snake ${ }^{27}$. In January, 2017, a man in Florida was accused of having sex with a pitbull, his female dog, on more than 100 occasions $^{28}$.

We've had some horrific news of these pratices in Portugal and Spain as well in recent years. For example, in Girona in 2010, a man declared to the media that 30 of his sheep had been stolen and that the thieves sent him a movie of one of the animals being sexually abused ${ }^{29}$. Later, in Spain, a man was caught having sex with his own female $\operatorname{dog}^{30}$. There was a case shared in Portugal's newspapers in May of 2016 claiming that a 80 year old man was suspected of mistreating and sexually abusing two female dogs in the city of Santarém ${ }^{31}$. Still in 2016, another man was found to own hundreds of files with child pornography and was a subscriber of a paid online channel of animal pornography ${ }^{32}$.

As a matter of fact, the internet plays a huge role in the presence of zoophilia nowadays. Pornographic content on the Internet involving animals is extremely easy to find. There are erotic stories, videos and even personal stories available and easily accessible. Some websites even provide instructions on how to engage in sexual contact with different species. Additionally, the internet is a common way for zoophiles to get in contact with each other via chatrooms ${ }^{33}$.

By simply typing a few keywords into a search engine (e.g., Google) it is extremely easy to find pornography online. Every day, up to $25 \%$ (68 million) of all Internet search engine requests are for pornography ${ }^{34}$.

Online you can find the most sadistic videos involving animal sexual abuse, including mutilation, torturing, beating and burning animals. Sometimes animals need to be sedated, tranquilised or stunned to make such kinds of abuse possible. Crush videos ${ }^{35}$ are a good example of these kind of sadistic practices available online ${ }^{36}$.

\section{Is Zoophilia a mental disorder?}

Several studies prove that sexual contact with animals is not as uncommon as we may think it is. For instance, Kinsey, Pomeroy and Martini, in 1948, studied the sexual behaviour of 5300 American men and reported that 1 in 13 men have had sexual relations with animals. Although the majority of these men were farm boys who had sex only with animals on many occasions, the study included men in their 50s and also one man over 80 years old ${ }^{37}$. Later, in 1953, the sexual behaviour of 5792 American women was analysed by the same investigation team. Results showed that $5 \%$ of those women had already had sexual relations with animals ${ }^{38}$. The data gathered by Hunt in 1974 concluded that the prevalence rate for zoophilia was $4.9 \%$ for men and $1.9 \%$ for women ${ }^{39}$.

Alvarez and Freinhar (1991) reported that 55\% of psychiatric patients enrolled in the study had at least one sexual fantasy or contact with animals ${ }^{40}$. A study involving a sample of college students, led by

\footnotetext{
${ }^{27}$ Snake sex video doctor found guilty. BBC News. Retrieved from: http://www.bbc.com/news/uk-england-london-37247160 (2016).

${ }^{28}$ Florida dog owner, 23, accused of having sex more than 100 times with his pitbull named Baby Girl. Mail Online (2017). Retrieved from: http://www.dailymail.co.uk/news/article-4118642/Man-accused-having-sex-100-times-pit-bull-named-BabyGirl.html.

${ }^{29}$ Roban una oveja la violan y lo graban en video. La Razón. Retrieved from: http://www.larazon.es/historico/4605-roban-unaoveja-la-violan-y-lo-graban-en-video-JLLA_RAZON_299238 (2010).

30 MARTÍNEZ, J. Imputado por maltrato animal tras praticar sexo co su perra. Lasprovincias.es (2012). Retrieved from: http://www.lasprovincias.es/v/20121030/sucesos/imputado-maltrato-animal-tras-20121030.html.

${ }^{31}$ Suspeito de violar cadelas em Santarém. Correio da Manhã. Retrieved from: http://www.cmjornal.pt/portugal/detalhe/suspeito_de_violar_cadelas_em_santarem (2016). http://www.cmjornal.pt/portugal/detalhe/20160326 2324_ve_criancas_violadas_e_sexo_com_animais (2016).

${ }_{33}$ BEETZ, A. Love, Violence and Sexuality in Relationships between Humans and Animals. Doctoral dissertation. (Germany 2002).

${ }^{34}$ ROPELATO, J. Internet pornography statistics. (2006). Retrieved from: http://internet-filter-review.toptenreviews.com/internetpornography-statistics.html.

35 "Crush vídeos" are vídeos where normally woman slowly torture and kill animals with stiletto shoes or their bare feet. See Beerworth, A. A.(2001) "United States v. Stevens: a proposal for criminalizing crush videos under current free speech doctrine" Vermont Law Review. 35:901

36 STERN A. W. SMITH-BLACKMORE, M. Veterinary Forensic Pathology of Animal Sexual Abuse. Veterinary Pathologyis:

${ }^{37}$ KINSEY, A. C., POMEROY, W. B. and MARTIN, C. E. Sexual Behavior in the Human Male. Saunders Company. (Philadelphia 1948).

${ }^{38}$ KINSEY, A. C., POMEROY, W. B. and MARTIN, C. E. and GEBHARD, P. H. Sexual Behavior in the Human Female. Saunders Company. (Philadelphia 1953).

${ }^{39}$ HUNT, M. Sexual Behavior in the 1970s. (New York 1974).

${ }^{40}$ ALVAREZ, W. A. FREINHAR, J. P. A prevalence study of bestiality (zoophilia) in psychiatric in-patients, medical in-patients, and psychiatric staff. International Journal of Psychosomatics 38 (1991) 45-47.
} 
Henry in 2004, revealed that both men and women admitted having sexual relations with animals in the past $^{41}$. Despite the referred studies, there is still a huge lack in research on the prevalence of sexual contact with animals in the total population.

Recently, data from 16 tertiary urology or oncology centers was collected in 12 Brazilian cities. All 492 subjects (118 patients and 374 controls) lived in rural zones during childhood and adolescence and were exposed to animal contact. The results showed that $31.6 \%$ of men in the control group and $44.9 \%$ of patients with penile cancer had already had sexual relations with animals ${ }^{42}$. Following this study in 2016 a report case regarding a 52 year old farmer with penile carcinoma also pointed to the possible relation between zoophilia and penile cancer ${ }^{43}$. Actually, there are several possible injuries in humans when sexual contact with animals happens, for example penile injuries ${ }^{44}$, rectal trauma ${ }^{45}$ and anal injuries ${ }^{46}$. The media does not often discuss the health risk of these contacts; neither do animal rights advocates or lawmakers. Several zoonoses can be transmitted via sexual contact between animals and humans, such as leptospirosis, echinococcosis and rabies ${ }^{47}$.

In order to get an insight into the reasons why people participate in this kind of sexual contact with animals, many studies have been developed. Miletski's study, in 2002, concluded that people who had sexual contact with animals had love feelings for animals, fantasies and sexual attraction. Some participants even reported that they were happy and didn't intend to stop having sex with animals ${ }^{48}$. What's more, the majority of participants in Beetz's study reported that the reason for having sex with animals was "innate" 49 , and in the William and Weinberger study $70 \%$ of participants chose the option "sex with animals is pleasurable" to justify those acts ${ }^{50}$. Furthermore, Beirne believes there are four main reasons why people engage in sexual activities with animals: sexual fixation on animals, sexual commodification, adolescent sexual experimentation and aggravated cruelty ${ }^{51}$.

Although people often associate animal sexual abuse with farmers or less educated people, some studies revealed quite the opposite: people who have sexual relations with animals tend to have more education than the general population ${ }^{52} 5354$.

As a way to describe the different levels of attraction towards animals, Donofrio (1996) suggested the use of a similar scale to Kinsey's scale ${ }^{55}$, starting at 0 , regarding people with no attraction to animals, up to 6, attributed to people exclusively attracted by animals. Scores in the middle would correspond gradually to: 1 - people who have animal sexual contact just in their fantasies or had incidental experiences with animals; 2 - someone who had more than incidental sexual contact with animals; 3 - people that have the same amount of sexual relations with animals as with humans; 4 - individuals who prefer sexual relations with animals but have some relations with humans; 5 - individuals that have primarily sexual relation with animals and just some incidental human sexual relations ${ }^{56}$.

\footnotetext{
${ }^{41}$ Henry BC. The relationship between animal cruelty, delinquency, and attitudes toward the treatment of animals. Soc Anim. 2004;12:185-207.

42 ZEQUI, S. C. et al. Sex with Animals (SWA): Behavioral Characteristics and Possible Association with Penile Cancer. A Multicenter Study. Journal of Sexual Medicine. 9/7 (2012) 1860-7

${ }^{43}$ ACOSTA-GUEVARA C, CALDERÓN-CARVAJALA, L. TORRESA, L. ROSSELLI, D. Cáncer de pene y sexo con animales: a propósito de un caso. Revista de Urolología Colombiana (2016).

${ }_{44}$ MITTAL, A. SHENOI, S. D. KUMAR, K. B. (2000) Genital lesions following bestiality. Indian. J Dermatol Venereol Leprol.;66:95-96

${ }^{45}$ KIROV G.K, LOSANOFF, J.E, KJOSSEV K. Zoophilia: a rare cause of traumatic injury to the rectum. Int J Care Injured. 33 (2002) 367-368.

${ }^{46}$ BLEVINS, R.O. A case of severe anal injury in an adolescent male due to bestial sexual experimentation. J Forensic Leg Med.16 (2009) 403-406.

${ }^{47}$ SINGG, S. Health Risks of Zoophilia/Bestiality. J Biol Med Science. 1/1 (2017).

${ }^{48}$ MILETSKI, H. Understanding Bestiality and Zoophilia. East West Publishing (Bethesda 2002).

${ }^{49}$ BEETZ, A. Love, Violence and Sexuality in Relationships between Humans and Animals. Doctoral dissertation. (Germany 2002).

${ }^{50}$ WILLIAMS J. W. and WEINBERG M. S. Zoophilia in men: A study of sexual interest in animals. Archives of Sexual Behavior $32 / 6(2003) 523-535$.

${ }^{51}$ BEIRNE, P. Rethinking bestiality: Towards a concept of interspecies sexual assault. Theoretical Criminology 1/3 (1997) 317-340.

${ }^{52}$ MILETSKI, H. Understanding Bestiality and Zoophilia. East West Publishing (Bethesda 2002).

${ }^{53}$ KINSEY, A. C., POMEROY, W. B. and MARTIN, C. E. Sexual Behavior in the Human Male. Saunders Company. (Philadelphia 1948).

${ }^{54}$ KINSEY, A. C., POMEROY, W. B. and MARTIN, C. E. and GEBHARD, P. H. Sexual Behavior in the Human Female. Saunders Company. (Philadelphia 1953).

55 The Kinsey Scale is an idea developed by Alfred Kinsey in 1948 that instead of describing people as either homosexual, heterosexual or bisexual sexual orientation was really a scale from heterosexuality to homosexuality. People at " 0 " report exclusively heterosexual / opposite sex behavior or attraction. Those at "6" report exclusively homosexual / same-sex behavior or attraction. Ratings 1-5 are for those who report varying levels of attraction or sexual activity with either sex. In the original Kinsey Report studies, the X category designated the group who reported no socio-sexual contacts or reactions in their interviews. See in: https://www.kinseyinstitute.org/research/publications/kinsey-scale.php.
}

${ }^{56}$ DONOFRIO, R. Human/animal sexual contact: A descriptive-exploratory study. Doctoral dissertation. The Institute for Advanced 
The first time zoophilia was listed as a paraphilia ${ }^{57}$ in the Diagnostic and Statistical Manual of Mental Disorders (DSM-III) was in 1980 with the definition: "The act or fantasy of engaging in sexual activity with animals is repeatedly preferred or the exclusive method of achieving sexual excitement" 58 . In the next edition DSM-IV the American Psychiatric Association (APA) included zoophilia in the "paraphilias not otherwise specified". According to the American Psychiatric Association (APA), animal abuse is one of the symptoms of a psychological dysfunction and they claim "zoophilia is virtually never a clinically significant problem by itself" $"$. In the latest edition, DSM-V, zoophilia is still included in "other specified paraphilic disorder". This means zoophilia is not considered a diagnosable mental health problem unless it causes distress to the person who engages in the practice ${ }^{60}$. Likewise, The International Classification of Diseases (ICD) refers to patterns of sexual preference and activity and includes a reference to sexual contact with animals and it does not classify it as a disease by itself ${ }^{61}$.

\subsection{Relation with other forms of abuse}

There is a clear connection between bestiality and violence. However, research on this area only supports the association with violent cases of bestiality ${ }^{62}$. The link between animal cruelty and interpersonal violence is well established ${ }^{636465}$ but there is still insufficient research to support the link between animal sexual abuse and interpersonal violence ${ }^{66}$. Besides that, there have been some studies that indicate that zoophilia is often associated with other paraphilias and/or violent behaviours.

Abel and his collaborators (1988) reviewed 14 cases of bestiality in a sample of 561 adult male patients diagnosed with a paraphilia and verified that bestiality was most commonly associated with incestuous and non-incestuous female pedophilia, voyeurism and exhibitionism ${ }^{67}$. When they questioned a group of prisoners, Miller and Knutson (1997) reported that $11 \%$ of the individuals had seen or engaged in sexual contact with animals ${ }^{68}$. The following year, Duffield and his colleagues (1998) found that $20 \%$ of children who sexually abused other children had already sexually abused animals, suggesting that zoophilia can be an indicator that other paraphilias may exist in the patient ${ }^{69}$. Later, in 2002, Fleming and his collaborators studied a group of institutionalized male adolescents and reported $6 \%$ of the 381 individuals affirmed having had sexual relations with animals and $96 \%$ of them also reported sex offenses against humans $^{70}$. Another relevant study on this subject with 180 adult participants who had committed child sexual abuse revealed that $36.1 \%$ of the individuals also had sexual relations with animals ${ }^{71}$.

Current research on animal sexual abuse supports the view that this behaviour during childhood may predict violent behaviours or abnormal sexual behaviours in adulthood. Hensley, Tallichet and Singer (2006) investigated groups of prisoners and reported that $75 \%$ of subjects who had sexual relations during their infancy or adolescence with animals had been convicted of crimes against people, including rape and murder. Indeed, only $5 \%$ of prisoners convicted of crimes against persons did not have a history of animal

\footnotetext{
Study of Human Sexuality (San Francisco 1996).

57 Definition of paraphilia: "recurrent, intense sexually arousing fantasies, sexual urges, or behaviors generally involving 1) nonhuman objects, 2) the suffering or humiliation of oneself or one's partner, or 3) children or other nonconsenting persons, that occur over a period of at least six months (Criterion A). ... The behavior, sexual urges, or fantasies cause clinically significant distress or impairment in social, occupational, or other important areas of functioning (Criterion B).” (APA 1994, p. 523)

${ }^{58}$ APA. Diagnostic and Statistical Manual of Mental Disorders. 3rd edn. American Psychiatric Association (Washington DC 1980).

${ }^{59}$ APA Diagnostic and Statistical Manual of Mental Disorders. 4th edn. (Washington D.C 1994).

${ }^{60}$ APA Diagnostic and Statistical Manual of Mental Disorders. 5th edn. (Washington D.C 2013).

${ }^{61}$ World Health Organization (WHO) (1992). The ICD-10 Classification of Mental and Behavioural Disorders. WHO: Geneva

${ }^{62}$ BEETZ, A. Bestiality and zoophilia: Associations with violence and sex offending. In Bestiality and Zoophilia - Sexual Relations with Animals. Purdue University Press (Indiana 2005) 46-70.

${ }^{63}$ ARKOW P. Child abuse, animal abuse, and the veterinarian. J Am Vet Med Assoc. 204/7 (1994) 1004-1007.

${ }^{64}$ ARKOW $P$. The correlations between cruelty to animals and child abuse and is ithe implications for veterinary medicine. Can Vet J. 33/8 (1992) 518-521.

${ }^{65}$ HELLMAN, D. S., BLACKMAN, N. Enuresis, firesetting and cruelty to animals: a triad predictive of adult crime. American Journal of Psychiatry 122 (1966) 1431-1435.

${ }^{66}$ BEETZ, A. Bestiality and zoophilia: Associations with violence and sex offending. In Bestiality and Zoophilia - Sexual Relations with Animals. Purdue University Press (Indiana 2005) 46-70.

${ }^{67}$ ABEL, G. G., BECKER, J.V., CUNNINGHAM-RATHNER, J., MitTleMAN, M., ROULEAU, J. L. Multiple paraphilic diagnoses among sex offenders. Bull Am Acad Psychiat Law. 16/2 (1988) 153-168.

${ }^{68}$ MILLER, K. S., KNUTSON, J. F. Reports of severe physical punishment and exposure to animal cruelty by inmates convicted of felonies and by university students. Child Abuse and Neglect 21/1 (1997) 59-82.

${ }^{69}$ DUFFIELD, G. HASSIOTIS, A. VIZARD, E. Zoophilia in young sexual abusers. J Forensic Psychiatry. 9 (1998) $294-304$.

${ }^{70}$ FLEMIN, W. M. JORI, B. BURTON, D. L. Characteristics of juvenile offenders admitting to sexual activity with nonhuman animals. Society and Animals.10 (2002) 31-45.

${ }^{71}$ ENGLISH, K. JONES, L. PATRICK, D. Sexual offender containment: use of post conviction polygraph. Ann NY Acad Sci. 989 (2003) 411-427.
} 
sexual contact in their infancy or adolescence ${ }^{72}$. Later, in 2010, the same group of investigators reported results consistent with the previous ones. They studied a group of prisoners who had sexual contact with animals during their childhood or adolescence and found they were more likely to commit crimes against people and to revert to these behaviours in adulthood, compared to the individuals who had not engaged in sexual acts with animals ${ }^{73}$. As a matter of fact, in 2008 Abel affirmed that animal sexual abuse committed during childhood is a strong predictor of committing child abuse as an adult ${ }^{74}$. More recently, in 2014, Schenk and collaborators showed significant result in their study, comprising this view: $81.25 \%$ of juvenile individuals who committed sexual offenses against humans admitted having had sexual relations with animals during childhood ${ }^{75}$.

Regarding the consumption of animal pornography, in 2013 Seigfried-Spellar and Roger surveyed 630 adult men and women on pornography consumption with bestiality, as well as child pornography consumption and concluded that users who watched child pornography were more likely to watch animal pornography ${ }^{76}$. Very recently, in 2016, Seigfried-Spellar confirmed that, statistically, individuals who consumed adult pornography were more likely to consume animal pornography, and animal pornography users were statistically more likely to consume child pornography ${ }^{77}$.

There seems to be a link between the abuse of animals and the abuse of humans. Animal abusers are known to exhibit violence towards their own relatives more often than strangers ${ }^{78}$. For that reason, veterinarians are the ones who can help break the cycle of family violence by reporting suspicious cases ${ }^{79}$.

\section{The Veterinarian's role}

Veterinarians are an essential tool to access information on animal abuse cases. Besides this, they can help to prevent some offenders from committing more crimes against other animals by reporting cases to authorities ${ }^{80}$. Unfortunately, animal sexual abuse is a difficult and uncomfortable issue and it may be considered taboo, even in the veterinary community ${ }^{81}$.

Veterinarians can be called to give expert testimonies on cases of animal abuse and mistreatment. Therefore, all veterinarians should be properly prepared and informed ${ }^{82}$. Most of the time they will be asked to submit an expert report which is vital to the court case ${ }^{83}$. Although, when talking about sexual abuse, the problem relies on the fact that this subject is rarely mentioned in veterinary textbooks. For example, obstetric/gynecology veterinarian textbooks almost never mention sexual abuse as a differential diagnosis of vaginal injuries ${ }^{84}$.

The veterinary pathology field has a special relevance as it can provide evidence on how the abuse happened. Indeed, veterinary pathologists can access detailed information regarding the physical injuries of the animal, as they provide some insights on methods and possible motives for committing such acts. Histopathology and forensic examinations are crucial in criminal investigations and prosecutions ${ }^{85}$. Recently, in 2016, Stern and Smith-Blackmore outlined a forensic investigation approach to the body of a suspected victim of sexual abuse, including an alternate light source examination, collection of swabs for

\footnotetext{
${ }^{72}$ HENSLEY, C., TALLICHET, S.E. \& SINGER, S.D. Exploring the possible link between childhood and adolescent bestiality and interpersonal violence. Journal of Interpersonal Violence, 21 (2006) 910-923.

${ }^{73}$ HENSLEY, C., TALLICHET, S.E. \& DUTKIEWICZ, E. L. Childhood bestiality: A potential precursor to adult interpersonal violence. Journal of Interpersonal Violence 25 (2010) 557- 567.

${ }^{74}$ ABEL, G. G. (2008). What can 44,000 men and 12,000 boys with sexual behavior problems teach us about preventing sexual abuse? Paper presented at the annual training conference of the California coalition on sexual offending, San Francisco, CA.

75 SCHENK, A. M. COOPER-LEHKI, C. KEELAN, C. M. FREMOUW, W. J. Underreporting of bestiality among juvenile sex offenders: Polygraph versus self-report. Journal of Forensic Sciences, 59 (2014) 540-542.

76 SEIGFRIED-SPELLAR, K.C., ROGER, M.K. Does deviant pornography use follow a guttman-like progression? Computers in Human Behavior. 29 (2013) 1997-2003.

${ }^{77}$ SEIGFRIED-SPELLAR, K.C. Deviant pornography use: The role of early-onset adult pornography use and individual differences. International Journal of Cyber Behavior, Psychology and Learning, 6/3 (2016) 34-47.

78 THIEL, D. A resource for veterinarians on recognizing and reporting animal abuse. Can Vet J, 43/2 (2002) 97-98.

79 CANADIAN VETERINARY MEDICAL ASSOCIATION (2011). Animal Abuse Position Statement. Retrieved from: http://www.canadianveterinarians.net/documents/animal-abuse.

${ }^{80}$ LOCKWOOD, R., ARKOW, P. Animal Abuse and Interpersonal Violence: The Cruelty Connection and Its Implications for Veterinary Pathology. Veterinary Pathology 53/5 (2016) 910-918.

${ }^{81}$ MUNRO, H. Animal sexual abuse: a veterinary taboo? The Veterinary Journal 172 (2006) 195-197.

82 GERDIN, J. A., MCFONOUGH, S. P. Forensic pathology of companion animal abuse and neglect. Vet Path Online. 50/6 (2013) 994-1006.

83 VOLLENHOVEN, E. V. SONNTAG, Q The Role of the Veterinarian in the Prosecution of Cases of Animal Abuse: Writing expert witness reports. (N.D)

${ }^{84}$ MUNRO, H., THRUSFIELD, M. Battered pets: sexual abuse. Journal of Small Animal Practice 42 (2001) 333-337.

${ }^{85}$ LOCKWOOD, R., ARKOW, P. Animal Abuse and Interpersonal Violence: The Cruelty Connection and Its Implications for Veterinary Pathology. Veterinary Pathology 53/5 (2016) 910-918.
} 
DNA analysis, sampling vaginal washes, rectal washes and toenails for trace evidence and biologic analyses; radiographic studies and a complete forensic necropsy, including histopathology ${ }^{86}$.

Veterinary clinicians also have an important role in detecting cases of sexual abuse. Generally, the clinicians will only suspect that sexual contact occurred if the animal presents suspicious injuries at the examination ${ }^{87}$. Surely cases of sexual abuse (even with penetration) are extremely difficult to detect in the veterinary clinic $^{88}$.

Another important fact to note is that people with pets would prefer to report a suspected mistreatment to the clinician than to a law entity ${ }^{89}$. Thus, veterinarians have a role as advocates for animals welfare and are crucial in the prevention of animal abuse ${ }^{90}$. However, very few studies have tried to access the relevance of animal sexual abuse in the veterinary community. Munro and Thrusfield (2001) analysed cases reported by 404 veterinarians in the UK. The results showed that $6 \%$ of those veterinarians reported sexual abuse. This study showed for the first time that animal sexual abuse is a huge and relevant problem that veterinarians encounter in their clinics ${ }^{91}$. A survey made in the Republic of Ireland in 2005 and also directed to veterinary surgeons detected only one case involving sexual abuse ${ }^{92}$. A few years later, in 2011, Williams and collaborators also used a questionnaire as a method to study the recognition of animal abuse by veterinarians. Their results were consistent with the Murno and Thrusfield study, reporting a $6 \%$ prevalence of sexual abuse ${ }^{93}$.

\section{Physical and psychological damage of the victim}

This sort of abuse can happen to several different species. It's not only with farm animals, as people may think. It has been reported on calves ${ }^{94}$, dogs, horses ${ }^{95}$, sheep, goats, swine, cats, fowls and even with dolphins ${ }^{96}$.

The size and anatomy of the abused animal are important factors to take into account when analysing the possible injuries caused by sexual intercourse. To give an illustration, intercourse between a large animal and a human may not result in physical damage while with a small animal the damage could be huge ${ }^{97}$.

Sometimes, these abuses can cause severe injuries and the animal may even die $^{98}$. Still, not all cases of animal sexual abuse present obvious injuries. Munro speculated that this sort of abuse towards animals is similar to cases towards children: extremely hard to recognize because it is possible that there are no injuries ${ }^{99}$. Ascione, in 1993, had already identified the parallel with children sexual abuse, considering all the cases cruel even if there is no physical harm towards the animal, as it is impossible for the animal to consent to the act ${ }^{100}$. There have not yet been rigorous investigations into animal behaviour to prove that there are psychological injuries in cases of sexual abuse. However, assuming those injuries do not exist is also wrong ${ }^{101}$.

Physical injuries vary depending on the type of sexual acts, the animal's size, what the abuser used to

\footnotetext{
86 STERN A. W. SMITH-BLACKMORE, M. (2016) Veterinary Forensic Pathology of Animal Sexual Abuse. Veterinary Pathology:

${ }^{87}$ BEETZ, A. Bestiality and zoophilia: Associations with violence and sex offending. In Bestiality and Zoophilia - Sexual Relations with Animals. Purdue University Press (Indiana 2005) 46-70.

${ }^{88}$ BEETZ, A. Love, Violence and Sexuality in Relationships between Humans and Animals. Doctoral dissertation. (Germany 2002).

${ }^{89}$ ENNS, A. MVMA Public Awareness and Attitude Survey, Final Report. Winnipeg: Enrg Research Group, Manitoba Veterinary Medical Association (2006).

${ }^{90}$ ARKOW, P. Recognizing and responding to cases of suspected animal cruelty, abuse, and neglect: what the veterinarian needs to know. Veterinary Medicine: Research and Reports: 6 (2015).

${ }^{91}$ MUNRO, H., THRUSFIELD, M. Battered pets: sexual abuse. Journal of Small Animal Practice 42 (2001) 333-337.

92 MCGUINNESS, G. ALLEN, M. JONES, B. R. Non-accidental injury in companion animals in the Republic of Ireland. Irish Veterinary Journal: 58/7 (2005)

93 WILliamS, V. M. DALE, A. R. ClARKE, N. GARRETT, N. K. G. Animal abuse and family violence: Survey on the recognition of animal abuse by veterinarians in New Zealand and their understanding of the correlation between animal abuse and human violence. New Zealand Veterinary Journal, 56/1 (2008) 21-28.

94 HVODZÍK BUGARSKY', A. KOTTFEROVA', J. VARGOVA', M. ONDRASOVICOVA',O. ONDRASOVIC, M, SASA'KOVA, N. Ethological, psychological and legal aspects of animal sexual abuse. The Veterinary Journal 172 (2006) 374-376

${ }^{95}$ BEETZ, A. Love, Violence and Sexuality in Relationships between Humans and Animals. Doctoral dissertation. (Germany 2002).

${ }^{96}$ MILETSKI, H. Understanding Bestiality and Zoophilia. East West Publishing (Bethesda 2002).

${ }^{97}$ BEETZ, A. Bestiality and zoophilia: Associations with violence and sex offending. In Bestiality and Zoophilia - Sexual Relations with Animals. Purdue University Press (Indiana 2005) 46-70.

${ }^{98}$ WEIDNER, E. Sodomie und Sadismus als Tierschutzproblem. Doctoral Dissertation. University of Giessen (Germany 1972).

${ }^{99}$ MUNRO, H., THRUSFIELD, M. Battered pets: sexual abuse. Journal of Small Animal Practice 42 (2001) 333-337.

100 ASCIONE, F. R. Children who are cruel to animals: a review of research and stepimplications for developmental psychopathology. Anthrozoo «̈. 6/4 (1993) ssepi226-247.

${ }^{101}$ MUNRO, H. Animal sexual abuse: a veterinary taboo? The Veterinary Journal 172 (2006) 195-197.
} 
assault and if an object was used, the form and size of $i^{102}$. Munro and Thursfield affirmed that the physical findings are quite similar to those found in human victims of sexual abuse. Some reported injuries are: vaginal and anal trauma with hemorrhage; uterine and cervix trauma; anal necrosis; anal dilatation; and damages in the scrotum and testicles ${ }^{103}$. In horses there have been reports of vaginal evisceration of the small intestine and the colon ${ }^{104}$ and injuries in the cloaca/vent in birds ${ }^{105}$. In Merck's opinion, recurrent vaginitis may also be indicative of sexual abuse. Inflicted injuries can be found outwith the genital area if the abuser uses their force to contain the animal. For example, if the aggressor pulls the tail, fractures of the coccygeal vertebrae may occur (see figure 2 ). If the act is committed by a zoosadist ${ }^{106}$, multiple injuries may be observed, as torture is a part of their sexual gratification. Sadistic actions can inflict countless injuries such as fractures, abrasions from fingernail scrapings and injuries in the optic canal ${ }^{107}$. Besides that, one of the most frequent causes of death in sexually abused animals is strangulation, similar to cases of human sexual assault ${ }^{108}$.

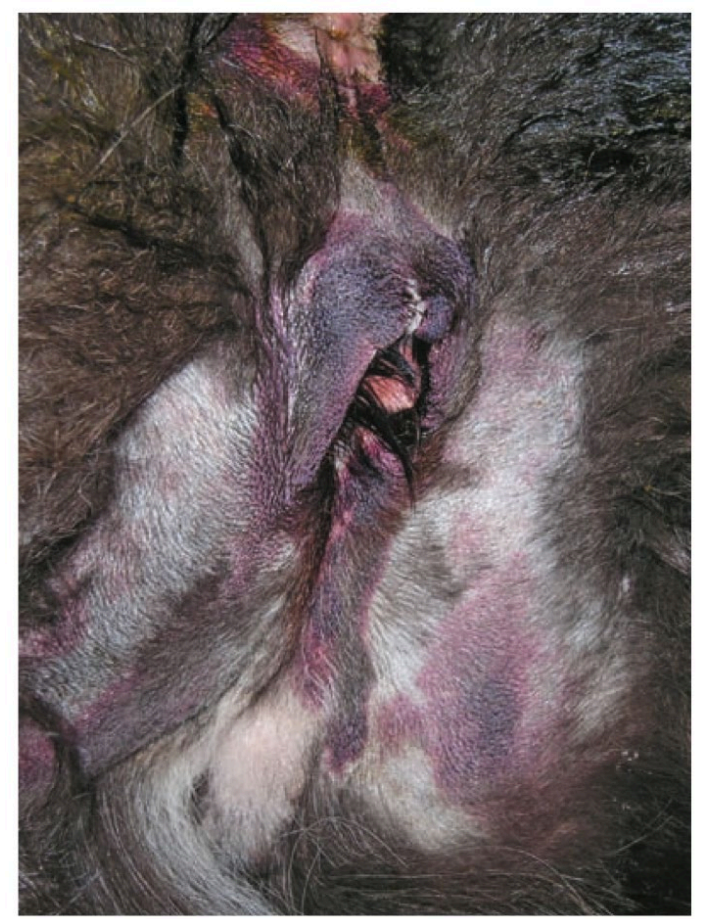

Figure 2 - Female dog victim of sexual abuse with several injuries: perianal subcutaneous hemorrhage resulting from a proximal tail fracture, external vulva abrasions, perivulvar bruising and medial thigh bruising (MERCK, 2007)

\section{Lack of legislation}

Only some countries in Europe prohibit the production, distribution and possession of pornography with zoophilia. For example, France prohibits sexual acts with animals in its Penal Code ${ }^{109}$. Germany has an animal protection law that also prohibits these kinds of acts ${ }^{110}$ and Denmark was one of the last European countries to ban zoophilia ${ }^{111}$.

${ }^{102}$ MERCK, M. D. Veterinary Forensics: Animal Cruelty Investigations. Blackwell Publishing (Australia 2007).

${ }^{103}$ MUNRO, H., THRUSFIELD, M. Battered pets: sexual abuse. Journal of Small Animal Practice 42 (2001) 333-337.

104 TULLENERS, E.P. RICHARDSON, D. W. REID, B.V. Vaginal evisceration of the small istepintestine in three mares. J Am Vet Med Assoc 186 (1985) 385-387..

${ }^{105}$ MUNRO, R. MUNRO, H. M. (2008) Animal abuse and unlawful killing. Forensic Veterinary Pathology. Philadelphia: Saunders.

106 According to Stern A. W. and Smith-Blackmore, M. Zoosadism is "an extreme form of sexual abuse that involves great suffering", "a zoosadist derives sexual pleasure from sadistic activities with an animal such as torture" and "sadism includes acts of genital mutilation". See STERN A. W. SMITH-BLACKMORE, M. (2016) Veterinary Forensic Pathology of Animal Sexual Abuse. Veterinary Pathology:SEP] $1-10$

${ }^{107}$ BRADLEY N, RASILE K. Recognition \& management of animal sexual abuse. Clinicians Brief (2014) 73-75.

${ }^{108}$ MERCK, M. D. Veterinary Forensics: Animal Cruelty Investigations. Blackwell Publishing (Australia 2007).

${ }^{109}$ French penal code. Available at:

https://www.legifrance.gouv.fr/affichCode.do;jsessionid=60573CE6403B3052DC7572BD09E32941.tpdila19v_1 ?idSectionTA=LE GISCTA000006149860\&cidTexte=LEGITEXT000006070719\&dateTexte $=20150409$

${ }^{110}$ German animal protection law. Available at: http://www.gesetze-im-internet.de/tierschg/_ 3.html.

${ }^{111}$ Denmark pases law to ban bestiality. BBC newsbeat. Retrieved from: http://www.bbc.co.uk/newsbeat/article/32411241/denmark- 
In the United States it differs according to the state. Of the 50 states, 45 have a provision that criminalizes engaging in sexual contact with animals. Hawaii, New Mexico, West Virginia and Wyoming, as well as the District of Columbia, do not have laws addressing this conduct ${ }^{112}$. For this reason, some zoophiles, as we can see on the British documentary Animal Passions, move from one state to another to be able to have sex with animals and even marry them in unofficial ceremonies ${ }^{113}$.

Pornography involving animals can be easily found in Spanish territory, as it is publicly available and legal ${ }^{114}$. In 2013, the Justice and Animal Defense Observatory (OJDA) made a report to the Draft Organic Law amending the LO 10/1995, dated November 23, of the Criminal Code, presented both to the Ministry of Justice of the Congress and the Senate of the different Political groups with parliamentary representation. After that, the art. $337.1 \mathrm{CP}$ has undergone modifications with respect to its previous regulation. Sexual exploitation of animals was added as an abuse, an issue not previously contemplated and that will give courts the power to punish such behaviours.

Art. $337.1 \mathrm{CP}^{115}$ : 1 . Shall be punished with the penalty of three months and one day to one year of imprisonment and special disqualification of one year and one day to three years for the exercise of profession, trade or commerce related to animals and animal husbandry, Who, by any means or procedure, mistreats them unjustifiably, causing them injuries that seriously impair their health or subject them to sexual exploitation, to:

a) a domesticated or tamed animal;

b) an animal of which are normally domesticated;

c) an animal that temporarily or permanently lives under human control;

d) any animal that does not live in the wild.

The Spanish legal system finally recognized that non-human animals can also be victims of sexual abuse and created legal tools to be able to pursue these behaviours. According to Rodríguez (2015), the current configuration of the crime of animal mistreatment as an offense makes it impossible to prosecute a sexual abuser, since not all kinds of animal sexual abuse may imply physical consequences. Furthermore, even if injuries are present, it is very difficult to prove the relation between such injuries and the act itself. Besides that, specific incorporation of the behaviour of subjecting an animal to sexual exploitation establishes it as an activity, not demanding a specific criminal charge result, as mere action constitutes the crime. The problem is that the term "sexual exploitation" is not new to Spanish legislators. This term is used several times in the Penal Code referring to humans and implies the element of profit. Therefore, it seems that the profit motive will also be an essential element to be considered by the judge when the sexual exploitation of animals is applied. Regrettably, this legislative decision runs the risk of protecting animals only against animal procuring, and not against any sexual abuser ${ }^{116}$.

Sánchez, lawyer of SPAP (Protector Society of Animals and Plants in Madrid) also believes that the word "exploitation" shouldn't be used since it connotes the concept of profit making. According to the dictionary of the Royal Spanish Academy (cited by Sánchez, N.D) "exploitation" means: 1. To take advantage of a business or industry for one's own benefit. 2. To use the work or the qualities of another person abusively for one's own benefit. To Sánchez "it would be more appropriate to include the criminalization of both sexual exploitation and the sexual abuse of animals. In this way, sexual abuses in the private sphere would be typified without leaving room for interpretive differences" 117 .

Another issue emphasized by Corbacho (2015) is that animals protected in this code are determined by a certain anthropocentrism since all those animals directly and indirectly depend on humans to subsist and are under our control and influence ${ }^{118}$. The author also believes that this reform, including the penalization of sexual abuse, was indispensable, since in most countries around Spain as well in the most

passes-law-to-ban-bestiality (2015).

112 WISCH, R. State animal sexual assault laws. (2017)

113 Animal Passions. Dir. Christopher Spencer. UK. 2004. Film.

114 BOLLIGER, G. GOETSCHEL, A. F. Sexual relations with animals (zoophilia): An unrecognized problemišepin animal welfare legislation. In Bestiality and Zoophilia - Sexual Relations with Animals. Purdue University Press (Indiana 2005) 23-45

115 Ley Orgánica 10/1995, de 23 de noviembre, del Código Penal

116 RODRÍGUEZ, N. La explotación sexual de animales en la Ley Orgánica 10/2015, de 30 de marzo, por la que se modifica el Código Penal español. Derecho animal - la webcenter de los animales con derecho. (2015) Obtained from www.derechoanimal.info/images/pdf/NML-Explotacion-sexual-CP.pdf

117 SÁNCHEZ, A. Respuesta judicial ante el maltrato animal: analisis de la aplicación del articulo 337 del código penal. Centro de estudios jurídicos. (N.D.)

118 CORBACHO, J. M. R. Comentario en relación al maltrato de animales en la nueva reforma del código penal Español (LO 1/2015. Derecho animal - la webcenter de los animales con derecho. (2015) Obtained from: http://www.derechoanimal.info/images/pdf/Corbacho-Reforma.pdf. 
developed ones, regarding animal law, there are legal provisions prohibiting all kinds of sexual abuse towards animals and prohibiting the use of non-human beings for sexual purposes ${ }^{119}$.

In May of 2017, Portugal changed the legal status of non-human animals from things to sentient beings. Besides the fact that this change was historical, and animals may no longer be "things" according to law, they are still used and abused as if they were ${ }^{120}$. Portuguese legislation has no explicit reference to sexual contact with animals. As a matter of fact, the only way to prosecute someone that has had a sexual encounter with an animal is by proving that the animal suffered pain or has any physical evidence of mistreatment ${ }^{121}$.

ART 387 CP: Animals mistreatment ${ }^{122}$

1. Who, without a legitimate motive, inflicts pain, suffering or any other mistreatment on a companion animal will be punished by prison up to one year or a fine up to 120 days.

2. If the facts provided for in the previous number result in the animal's death, the loss of a vital organ or member or the serious and permanent impairment of it's ability to move, the agent will be punished with prison up to 2 years or fine up to 240 days.

Bolliger and Goetschel, in 2005, argued that any sexual contact with animals should be prohibited, as with children and people with disabilities. Animals, similar to these individuals, cannot assert their legal position on their own and it should be irrelevant whether or not they get injured during sexual activity or whether they participated voluntarily. The authors affirm that "To put animals into this category with people, in respect of their being worthy of protection from sexual exploitation, is only a consistent development both ethically and legally, and does not constitute an improper humanization of animals." Additionally, they believe that all actions related to zoophilic pornography should be prohibited, such as production, distribution and even acquisition ${ }^{123}$.

\section{III - OBJECTIVES}

The principal aims of our study are:

- To survey veterinarians regarding their perceptions of and experiences with cases of suspected or confirmed animal sexual abuse;

- To establish the incidence and frequency of cases of sexual abuses detected by veterinarians in Portugal and Spain;

- Investigate the veterinarians' views on this subject and explore their attitude towards cases of animal abuse;

- Determine in which regions of Portugal and Spain zoophilic content is being searched for online;

- Motivate other investigators to focus on this subject;

- To show the urgent need to change legislation to protect the victims of these abuses.

\section{IV- METHODS AND MATERIAL}

To accomplish our goals we used two different approaches. Firstly, an online survey was made and directed to Portuguese and Spanish veterinarians. Secondly, an online tool was used to analyze the pornography-seeking behavior in those two countries.

\section{Survey directed to veterinarians}

Survey description - An anonymous online survey was created for this study (See Annex 1 with the Spanish version). We used this method following examples from previous similar studies 124125126127

\footnotetext{
${ }^{119}$ CORBACHO, J. M. R. Nuevos tiempos para el delito de maltrato de animales a la luz de la reforma del código penal español (LO 1/2015). Revista Electrónica de Ciencia Penal y Criminología (2016) 18-16.

${ }^{120}$ MENDONÇA, H. C. Recognising sentience in the Portuguese civil code. Derecho animal - la webcenter de los animales con derecho. (2017) Obtained from: http://www.derechoanimal.info/images/pdf/SentiencePortugueseCodeR.pdf.

${ }^{121}$ DUARTE, M. L. GOMES, C. A. Animais: Deveres e Direitos. Instituto de Ciências Júrido-Políticas (2015).

${ }^{122}$ Lei ${ }^{\circ}$ 69/2014 de 29-08-2014 CP-artigo 387 - Maus tratos a animais de companhia.

${ }^{123}$ BOLLIGER, G. GOETSCHEL, A. F. Sexual relations with animals (zoophilia): An unrecognized problemisepin animal welfare legislation. In Bestiality and Zoophilia - Sexual Relations with Animals. Purdue University Press (Indiana 2005) 23-45

${ }^{124}$ WILliAMS, V. M. DALE, A. R. CLARKE, N. GARRETT, N. K. G. (2008) Animal abuse and family violence: Survey on the recognition of animal abuse by veterinarians in New Zealand and their understanding of the correlation between animal abuse and 
and the developed, type of questions and methodology according to what has been suggested in the literature ${ }^{128}$. It was designed to be completed within five minutes. A draft survey was tested informally by six of the author's colleagues to detect unclear or ambiguous questions. All the necessary revisions and updates were made and the final survey was shared online. The survey was available from June 15 until July 15 . The first page had a brief paragraph describing the purpose of the project and encouraging the veterinarian's participation. This paragraph deliberately did not mention animal sexual abuse as the area of research, but only made a general statement about our interest in animal mistreatment. Respondents were also advised that the survey was anonymous and to be used for academic purposes only. The final survey consisted of a first set of survey questions ascertaining the demographic characteristics of the respondents, plus 10 questions about the subject. A total of 140 surveys were answered but only 111 were analysed. Surveys which had the same answers for all questions were excluded to avoid any error, in case someone accidentally participated multiple times.

Statistical analyses - All answers were organized in Excel sheets (Excel for Mac 2011®). The analysis of results was done with the help of version 23.0 of the software SPSS (Statistical Package for the Social Sciences) and the graphs/tables created with Excel. The answers to some questions conditioned the respondent in their answer for other questions, which is why certain results express frequencies of answers relating to fewer than the total of 111 respondents. The percentage of valid answers is greater than $98 \%$ for all questions.

The associations between the variables were studied by the chi-square test. In cases where more than $20 \%$ of the columns had $<5$ as expected, we used Fisher's test. Values of $p<0.05$ were considered statistically significant. We considered $\mathrm{p}<0.01$ very significant and $\mathrm{p}<0.001$ highly significant.

\section{Pornography-seeking behaviour analysed with Google Trends}

To analyse animal pornography-seeking behaviour in Portugal and Spain, we started by using the Internet service WordTracker to determine which keywords individuals tend to use to search for animal pornography. Keywords are the words individuals enter into various search engines in order to find something online. For example, a person might type the word "porn" or "sex" into the Google search engine when attempting to find pornography. By compiling data from millions of searches each week, WordTracker is able to identify the top keywords individuals tend to use to find pornography ${ }^{129}$. Then we used Google Trends to determine the popularity of these pornography keywords. Google Trends is a free and publically accessible online portal that analyses billions of daily Google searches, generating data on geographical and temporal patterns according to specified keywords ${ }^{130}$.

Participants for this study were any individuals residing in Portugal and Spain who entered select keywords into the Google search engine between $15^{\text {th }}$ July 2012 and $15^{\text {th }}$ July 2017.

\section{V - RESULTS AND DISCUSSION}

\section{Survey directed to veterinarians}

A total of 111 questionnaires were analysed. 71 respondents were Spanish and 40 Portuguese. Details of demographic data concerning each version of the survey are summarized in Table 1. Analysing the entire sample $(\mathrm{n}=111)$, most respondents were female $(\mathrm{n}=87) 78.4 \%$ whereas $24(21.6 \%)$ were male. Regarding the age of the participants, $24(21.6 \%)$ were between 20 and 29 years old, $45(40.5 \%)$ between 30 and 39 years

human violence. New Zealand Veterinary Journal, 56:1, 21-28.

${ }^{125}$ KOGAN, L. R. SCHOENFELD-TACHER, R. M. PHD, PETER W. HELlYER, P. W. RISHNIW, M. RUCH-GALLIE, R. A. Survey of attitudes toward and experiences with animal abuse encountersispin a convenience sample of US veterinarians. JAVMA. 250 (2017) 6.

${ }^{126}$ MUNRO, H., THRUSFIELD, M. Battered pets: sexual abuse. Journal of Small Animal Practice 42 (2001) 333-337.

${ }^{127}$ MCGUINNESS, G. ALLEN, M. JONES, B. R. Non-accidental injury in companion animals in the Republic of Ireland. Irish Veterinary Journal: 58/7 (2005)

${ }^{128}$ DILLMAN, D., SMYTH, J.D. AND CHRISTIAN, L.M. Internet, Mail and Mixed-Mode Surveys. The Tailored Design Method, John Wiley \& Sons Inc., Prince Edward Island, (Canada 2009).

${ }^{129}$ WordTracker Keyword Research Tools for SEO. (2017). Retrieved from: http://www.wordtracker.com/.

${ }^{130}$ CHOI, H. VARIAN, H. Predicting the present with google trends. Econ Record 88 (2012) 2-9. 
old, 39 (35.1\%) between 31 and 39 years old, followed by $13(11.75 \%)$ aged between 50 and 64 years old.

The years of veterinary school graduation were reported as 2011 to 2016 (31 [27.9\%]), 2001 to 2010 (44 [39.6\%]), 1991 to 2000 (23 [20.7\%]), 1981 to 1990 (11 [9.9\%]) and 1971 to $1980(2[1.8 \%])$.

The largest proportion of practicing veterinarians reported working in small animal practice $92.8 \%$ $(n=103)$ followed by mixed-animal practice $4.6 \%(n=4)$, large animals practice $2.7 \%(n=3)$ and others, which included one veterinarian working in the meat industry, a pathologist and a municipal veterinary. Furthermore, the majority of veterinarians spent more than $50 \%$ of their time treating small animals (11 $[9.9 \%])$.

\section{Table 1- Demographic data of the respondents}

\begin{tabular}{ccc}
\hline & \multicolumn{2}{c}{ Number (\%) } \\
\cline { 2 - 3 } Demographic & Portuguese Survey & Spanish Survey \\
\hline Gender & & \\
Male & $9(22.5 \%)$ & $15(21.1 \%)$ \\
Female & $31(77.5 \%)$ & $56(78.9 \%)$ \\
Age group & & \\
$20-29$ & $15(37.5 \%)$ & $9(12.7 \%)$ \\
$30-39$ & $13(32.5 \%)$ & $32(45.1 \%)$ \\
$40-49$ & $10(25 \%)$ & $19(26.8 \%)$ \\
$50-64$ & $2(5 \%)$ & $11(15.5 \%)$ \\
Year of graduation & $1(2.5 \%)$ & $1(1.4 \%)$ \\
$1971-1980$ & $1(2.5 \%)$ & $10(14.1 \%)$ \\
$1981-1990$ & $6(15 \%)$ & $17(23.9 \%)$ \\
$1991-2000$ & $11(27.5 \%)$ & $33(46.5 \%)$ \\
$2001-2010$ & $21(52.5 \%)$ & $10(14.1 \%)$ \\
$2011-2016$ & & $69(97.2 \%)$ \\
Practice type & $34(85 \%)$ & $1(1.4 \%)$ \\
Small animal & $3(7.5 \%)$ & 0 \\
Mixed & $1(2.5 \%)$ & $1(1.4 \%)$ \\
Large animals & $2(5 \%)$ & $70(98.6 \%)$ \\
Other & $39(97.5 \%)$ & 0 \\
More than 50\% of time spent treating & $1(1.4 \%)$ \\
Small animals & $1(2.5 \%)$ &
\end{tabular}

When respondents were asked whether they had encountered any cases of animal abuse (suspected or confirmed), $71(63.9 \%)$ reported that they had and 40 (36\%) reported that they had not. Taking a closer look into the data regarding each version of the survey individually, $24(60 \%)$ Portuguese veterinarians reported that they had encountered cases of animal mistreatment and $16(40 \%)$ had not. Regarding the Spanish version of the survey, results were similar; $47(66 \%)$ had faced or at least suspected cases of animal abuse and $24(34 \%)$ had not. These findings are remarkably similar to those found by Williams and collaborators in New Zealand, where $63 \%$ of veterinarians were reported to have seen cases of deliberate animal abuse ${ }^{131}$. These figures surpassed the ones found by Munro and Thrusfield (2001) in the UK, where $48.3 \%$ of the veterinarians had seen cases of mistreatment and in the results from the study made in Ireland by McGuinness, Allen and Jones in 2005, where $44.3 \%$ of respondents reported seeing cases of animal abuse. By contrast, a much higher percentage of veterinarians affirmed encountering cases of abuse in the USA $(87 \%)^{132}$.

More than half of the veterinarians of each country (Portugal and Spain) had faced a case that made them suspect or be certain of a case of mistreatment. Despite this, many cases may have gone unnoticed since it is sometimes difficult for the veterinarian to admit that a client would present a case of abuse to the

\footnotetext{
${ }^{131}$ WILliAMS, V. M. DALE, A. R. CLARKE, N. GARRETT, N. K. G. (2008) Animal abuse and family violence: Survey on the recognition of animal abuse by veterinarians in New Zealand and their understanding of the correlation between animal abuse and human violence. New Zealand Veterinary Journal, 56:1, 21-28.

132 KOGAN, L. R. SCHOENFELD-TACHER, R. M. PHD, PETER W. HELLYER, P. W. RISHNIW, M. RUCH-GALLIE, R. A. Survey of attitudes toward and experiences with animal abuse encountersispiin a convenience sample of US veterinarians. JAVMA. 250 (2017) 6. 
clinic $^{133}$. Besides that, most veterinarians make their diagnosis based on the assumption that the client is not lying during the anamnesis (collection of an animal's history) ${ }^{134}$. Moreover, it is extremely difficult to be sure that a mistreatment occurred. If there are no evident physical findings, the veterinarian needs to be aware of different things, such as if there is discrepancy between the history provided and the clinical findings or if explanations are vague and inconsistent ${ }^{135}$.

When asked if they had ever reported a case of animal mistreatment, only 17 (15.3\%) participants said they had while $94(84.7 \%)$ had not. Analyzing participants from each country individually, in Spain only $12(16.9 \%)$ participants had reported at least one case of animal mistreatment while only $5(12.5 \%)$ of the Portuguese veterinarians did. Relating these results with how many had seen or suspected cases of mistreatment, we concluded that from the 47 Spanish veterinarians who encountered cases of animal abuse, only $12(25.5 \%)$ had reported it. In the Portuguese survey, from the 24 participants who encountered confirmed or suspected of abuse cases, only $5(20.8 \%)$ reported them (Figure 1$)$.

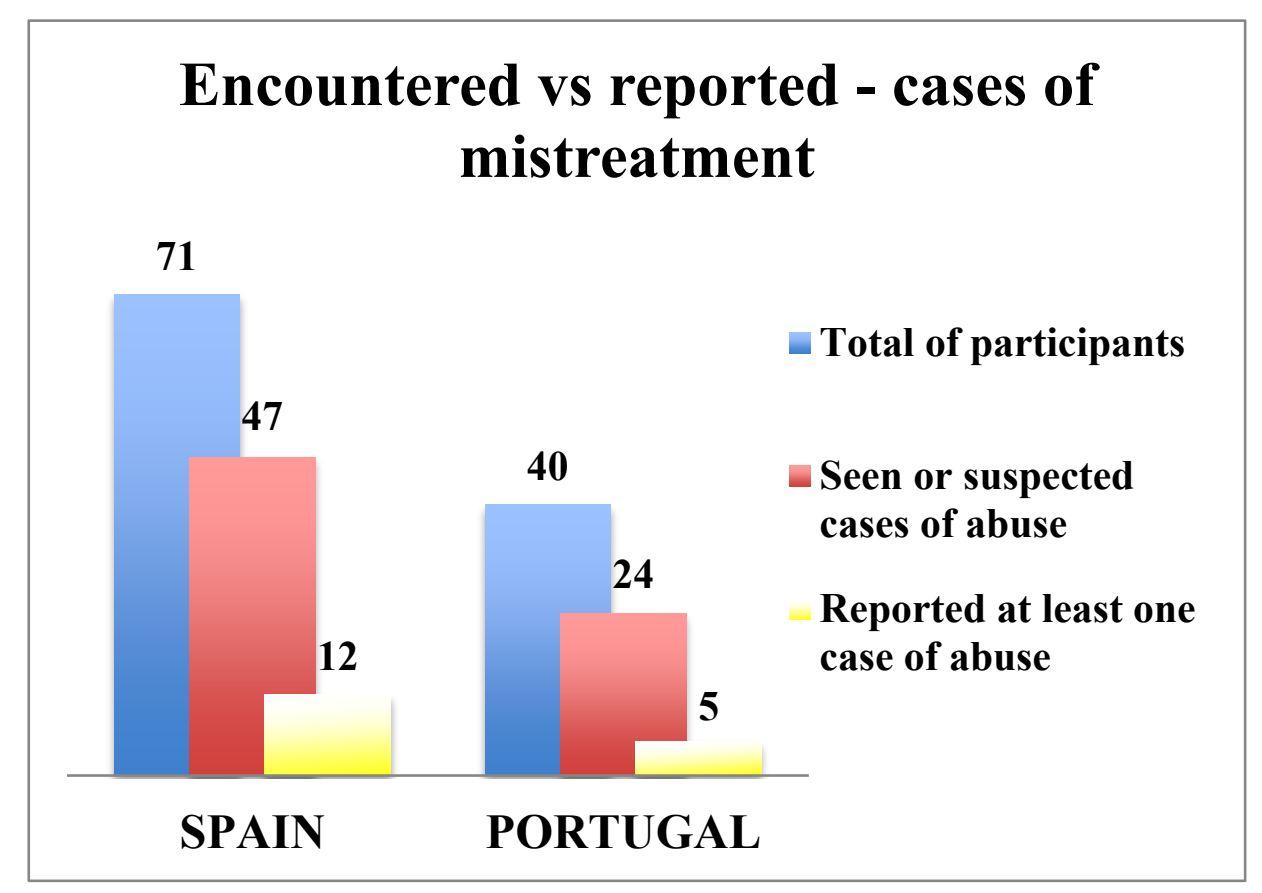

Figure 3- Graphic representation of veterinarians who encountered cases of mistreatment versus number of veterinarians who reported cases of mistreatment. Blue - total of participants in each country; Red - number of participants who had seen or suspected at least one case of animal mistreatment; Yellow - number of veterinarians who had at least reported one case of animal abuse during their practice.

According to McGuinness and collaborators, "Many professionals are reluctant to get involved due to fear of litigation, fear that the client will be driven away, fear of erosion of the client base of the practice, fear that reporting will compromise the safety of the victim, lack of knowledge of available resources, a perception that no action will be taken, fear of physical retaliation by the perpetrator, a lack of widelyaccepted standards of identification and inexperience in dealing with misleading histories" ${ }^{\prime 136}$. In the study made by Kogan and collaborators, veterinarians reported other motives for not reporting a suspected case of abuse: thinking it is better to educate the client than report the abuse, thinking it was accidental and not intentional, being unsure of the process for reporting, telling their superior or practice manager for them to decide what to do, fearing that the animal would suffer as a result of reporting, fearing retaliation by the abuser, fearing that they would damage their relationship with the client, fearing that they would harm the clinic's reputation, fearing that their own reputation would be harmed, lacking time or meaning to report it but not getting around to it ${ }^{137}$. Moreover, professional secrecy is one of the major obstacles to a possible

\footnotetext{
${ }^{133}$ MERCK, M. D. The veterinarian's role in animal abuse. (N.D)

${ }^{134}$ LOCKWOOD, R., ARKOW, P. Animal Abuse and Interpersonal Violence: The Cruelty Connection and Its Implications for Veterinary Pathology. Veterinary Pathology 53/5 (2016) 910-918.

${ }^{135}$ MERCK, M. D. The veterinarian's role in animal abuse. (N.D)

${ }^{136}$ MCGUINNESS, G. ALLEN, M. JONES, B. R. Non-accidental injury in companion animals in the Republic of Ireland. Irish Veterinary Journal: 58/7 (2005)

${ }^{137}$ KOGAN, L. R. SCHOENFELD-TACHER, R. M. PHD, PETER W. HELLYER, P. W. RISHNIW, M. RUCH-GALLIE, R. A. Survey of attitudes toward and experiences with animal abuse encountersiseppin a convenience sample of US veterinarians. JAVMA.
} 250 (2017) 6. 
report in Portugal and Spain.

The deontological code of Spanish veterinarians says in its article 8:

1. Veterinary secrecy is inherent in the exercise of the veterinary profession and is established as a right of the client to safeguard his or her privacy to third parties. The veterinarian is obliged to keep professional secrecy.

2. The obligation of professional secrecy extends to all matters known by the veterinarian by direct information of the client or to have known in the exercise of the profession. The veterinarian also has the duty to demand from his collaborators or employees, discretion and scrupulous observation of the professional secrecy that is also incumbent upon them.

3. Exceptionally, with discretion, only to those who have to do so, within their fair and restricted limits and, if he deems it necessary, requesting the advice of his Official College, the veterinarian may reveal the secret in the following cases:

a) When he obtains the express written permission of the client. However, this authorization should not prejudice the discretion of the veterinarian, who will always endeavor to maintain social trust and confidentiality.

b) By legal imperative.

c) Of a notifiable disease.

d) When the veterinarian considers that his silence could passively allow activity, counter to the best interest of animal welfare.

e) When the veterinarian is unfairly harmed by the maintenance of the secret of a client and the client is the voluntary author of the injury.

f) When the veterinarian is inquired by the College or is called to testify for a file made by another professional.

4. When the veterinarian ceases his professional activity, his files may be transferred to the veterinarian who succeeds, unless the clients express their will against, always with respect and compliance with current regulations ${ }^{138}$.

A closer look at the Spanish veterinarian deontological code seems to indicate that in all cases of suspected animal mistreatment, the veterinarian should report it, because according to 8.3.d the veterinary silence could prejudice the animal's welfare since the abuses may continue. We believe that regarding sexual abuse the same should apply, as we strongly believe that this is a form of mistreatment even if physical injuries are not present. However, deontological codes may differ in each autonomous region. For example, in Catalonia, article 32 regarding professional secrecy says:

32.1.- Professional secrecy may be raised in the following cases:

A) When the maintenance of the secret can cause a noticeably unfair and serious injury to a veterinarian or a third party.

B) When the veterinarian is authorized expressly by the client or his heirs.

C) In records of a disciplinary jurisdiction based on complaint or defense by his own initiative or required by the veterinary College.

32.2.- In the first two cases, the veterinarian interested in secrecy will have to request the Board of Directors or the member of the Board in which it delegates, which will authorize it if the requirements established in this article are met ${ }^{139}$.

Comparing the Portuguese veterinarian deontological code with the Spanish one, it is clear that the Portuguese one has fewer exceptions giving permissions to break the professional secrecy.

Art $22^{\circ}$ - Professional secrecy

1. Veterinarians are required to keep professional secrecy.

2. Professional secrecy covers all the facts of a reserved nature relating to professional matters that have been revealed to him by the client or known in the exercise of his profession, or in the performance of his duties in the Veterinary Medical Order.

3. The obligation of professional secrecy is not limited in time.

138 ORGANIZACIÓN COLEGIAL VETERINARIA ESPAÑOLA Código Deontológico para el ejercício de la profesión veterinaria (2006) Obtained from: http://www.colvet.es/node/165

${ }^{139}$ COLLEGI OFICIAL DE VETERINARIS DE BARCELONA Normes deontològiques comuns a la professió veterinaria catalane (2002). Obtained from: http://www.covb.cat/pdf/normes_deontologiques.pdf. 
Art $23^{\circ}$

The obligation of professional secrecy shall cease when:

A) The law so determines or the interested party authorizes it;

B) The defense of the dignity, rights and legitimate interests of the Veterinarian if such is recognized by the Professional and Deontological Council;

C) In the case of facts whose data came from literature, knowledge came from the ownership of an organ of the Order of the Veterinarians, this being recognized by the respective body or, being this singular, by the Professional and Deontological Council ${ }^{140}$.

In contrast with the Spanish deontological code, the Portuguese code has no mention of the animal's interests concerning the exceptions for breaking client secrecy. Unless the client presenting the animal in the veterinarian's practice is not the author of the abuse, it is extremely improbable that he would authorize ceasing professional secrecy. Besides that, the fact that veterinarians need to have authorization to report cases, tends to make investigations more difficult ${ }^{141}$.

When asked their views on being mandatory for veterinarians to report a case of animal mistreatment, $101(91.0 \%)$ answered it should be, while nine (8.1\%) answered it shouldn't. One participant didn't answer this question (Figure 4). There were no large differences between the two countries, as $92.5 \%$ of Portuguese veterinarians believe it should be mandatory to report and $91.4 \%$ of Spanish veterinarians agreed.

\section{"Do you think it should be mandatory for veterinarians to report cases of abuse?"}

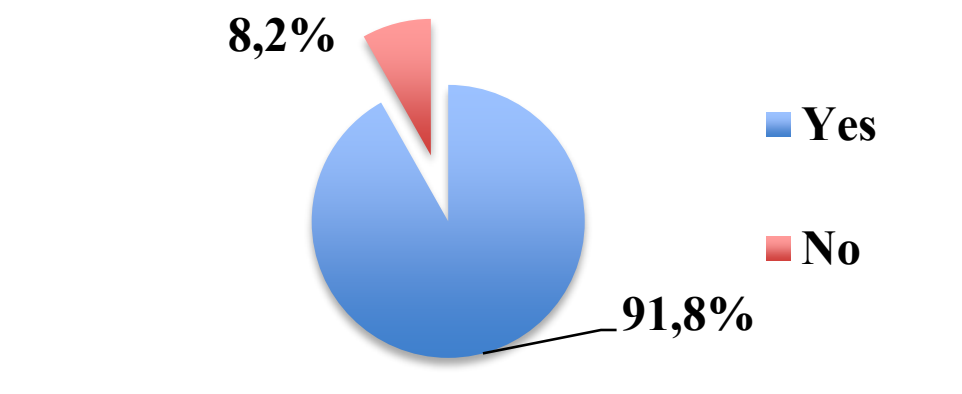

Figure 4 - Graphic representation of the answers to the question "Do you think it should be mandatory for veterinarians to report cases of abuse?"

No significant associations were identified between gender, age and the answer to this question. However, the association between this question and the year of graduation was statistically significant $(p=0.045$ in Fisher's exact test). As showed on table 2, all the recently graduated veterinarians (between 2011 and 2016) considered that it should be mandatory for veterinarians to report cases of mistreatment. On the other hand, veterinarians who considered that it should not be mandatory to report $(8.2 \%)$ graduated before 2011 .

140 ORDEM DOS MÉDICOS VETERINÁRIOS Código Deontológico Médico-Veterinário (2009) Obtained from: https://www.omv.pt/estatuto-e-codigo-deontologico/codigo-deontologico.

141 TOMÁS, C. 14 processos crime por maus-tratos a animais, mas só dois no tribunal. (2015) Available at: http://expresso.sapo.pt/sociedade/2015-10-29-14-processos-crime-por-maus-tratos-a-animais-mas-so-dois-no-tribunal. 
Table 2 - Influence of the variable "graduation year" on the answer to the question "Do you think it should be mandatory for veterinarians to report cases of abuse?" (Exact Fisher's test)

\begin{tabular}{llll}
\hline & No & Yes & P \\
\hline Graduation year & & & \\
$1971-1980$ & 0 & 2 & \\
$1981-1990$ & 3 & 8 & 0,045 \\
$1991-2000$ & 3 & 20 & \\
$2001-2010$ & 3 & 40 & \\
$2011-2016$ & 0 & 31 & \\
\hline
\end{tabular}

According to the Canadian Veterinary Medical Association (CVMA) veterinarians have a "moral obligation" to report suspected cases of animal mistreatment. We strongly agree with the opinion of CVMA that urges veterinary associations to lobby their governments to make reporting all kinds of animal abuse and mistreatment, including animal sexual abuse, mandatory. Besides, there should be immunity from civil and criminal liability for veterinarians that report such cases ${ }^{142}$.

Of the 111 respondents, $9(8.1 \%)$ had encountered (suspected or confirmed) at least one case of animal sexual abuse. There was a slight difference between frequencies of Portuguese and Spanish veterinarians who saw those cases: four veterinarians in Spain corresponding to a total of $5.6 \%$ of Spanish participants and five Portuguese veterinarians, corresponding to a total of $12.5 \%$ of the Portuguese participants. When asked how many cases of sexual abuse they had encountered, all the participants answered "one case" with the exception of one veterinarian who reported they had seen more than five cases. Our results were similar to the ones found by Murno and Thrusfield, in 2001, and Williams and collaborators, in 2008, both with a prevalence of $6 \%$ of cases of suspected sexual abuse ${ }^{143} 144$.

Of the respondents who reported having seen or at least suspected cases of animal sexual abuse, the reasons given for their suspicions were: "The owner told me because she knew the story firsthand"; "Anal and rectal lesions in a female dog"; "The owner consulted us believing her husband raped the dog"; "Foreign object in the sexual organ of a female dog"; "The behaviour of the animal relative to their guardian and the sexual history of the same"; "Profuse rectal and vulvar hemorrhage, edema and laceration of the rectal and vaginal area. The guardian said the female dog had been raped by a fellow dog ...but it seems impossible to me once the female was sterilized."; "Suspicious lesions in the genital area."; "Injuries incompatible with the story of the moment"; "Vaginal tears".

The reasons for suspecting sexual abuse are varied. The ones found in our study are in accordance with the ones found in Munro's study. In Munro's study, the four main reasons for suspecting animal sexual abuse were: the type of injury; the behaviour of the owner; statements from witnesses; and admission by the perpetrator ${ }^{145}$.

Besides the fact this subject is rarely mentioned in veterinary textbooks ${ }^{146}$, some veterinarians are aware of this kind of abuse and consider sexual abuse as a differential diagnosis of vaginal and anal injuries. However, our results show that most of the time clinicians will only suspect that sexual contact occurred if the animal presents suspicious injuries at the examination, sustaining the view of Beetz ${ }^{147}$.

We gave a list of options for veterinarians to select which they considered to be sexual abuse. Only one participant did not answer this question, so of the 110 participants who answered $100 \%$ considered the options "vaginally penetrate the animal" and "anally penetrate the animal" as sexual abuse. $94.5 \%$ of the veterinarians considered "practice oral sex on the animal" a kind of sexual abuse. Regarding the acts of being "anally penetrated by the animal" and being "vaginally penetrated by the animal" $92.7 \%$ of the participants considered it sexual abuse. Receiving oral sex from the animal was considered an abuse by

142 Canadian Veterinary Medical Association. Animal Abuse Position Statement (2011) Retrieved from: http://www.canadianveterinarians.net/documents/animal-abuse.

${ }^{143}$ MUNRO, H., THRUSFIELD, M. Battered pets: sexual abuse. Journal of Small Animal Practice 42 (2001) 333-337.

${ }^{144}$ WILLIAMS, V. M. DALE, A. R. CLARKE, N. GARRETT, N. K. G. (2008) Animal abuse and family violence: Survey on the recognition of animal abuse by veterinarians in New Zealand and their understanding of the correlation between animal abuse and human violence. New Zealand Veterinary Journal, 56:1, 21-28.

${ }^{145}$ MUNRO, H., THRUSFIELD, M. Battered pets: sexual abuse. Journal of Small Animal Practice 42 (2001) 333-337.

${ }_{146}$ MUNRO, H., THRUSFIELD, M. Battered pets: sexual abuse. Journal of Small Animal Practice 42 (2001) 333-337.

147 BEETZ, A. Bestiality and zoophilia: Associations with violence and sex offending. In Bestiality and Zoophilia - Sexual Relations with Animals. Purdue University Press (Indiana 2005) 46-70. 
$89.1 \%$ of the veterinarians and the lowest percentage corresponds to "masturbating the animal", which $80.9 \%$ of the participants considered sexual abuse (Figure 5).

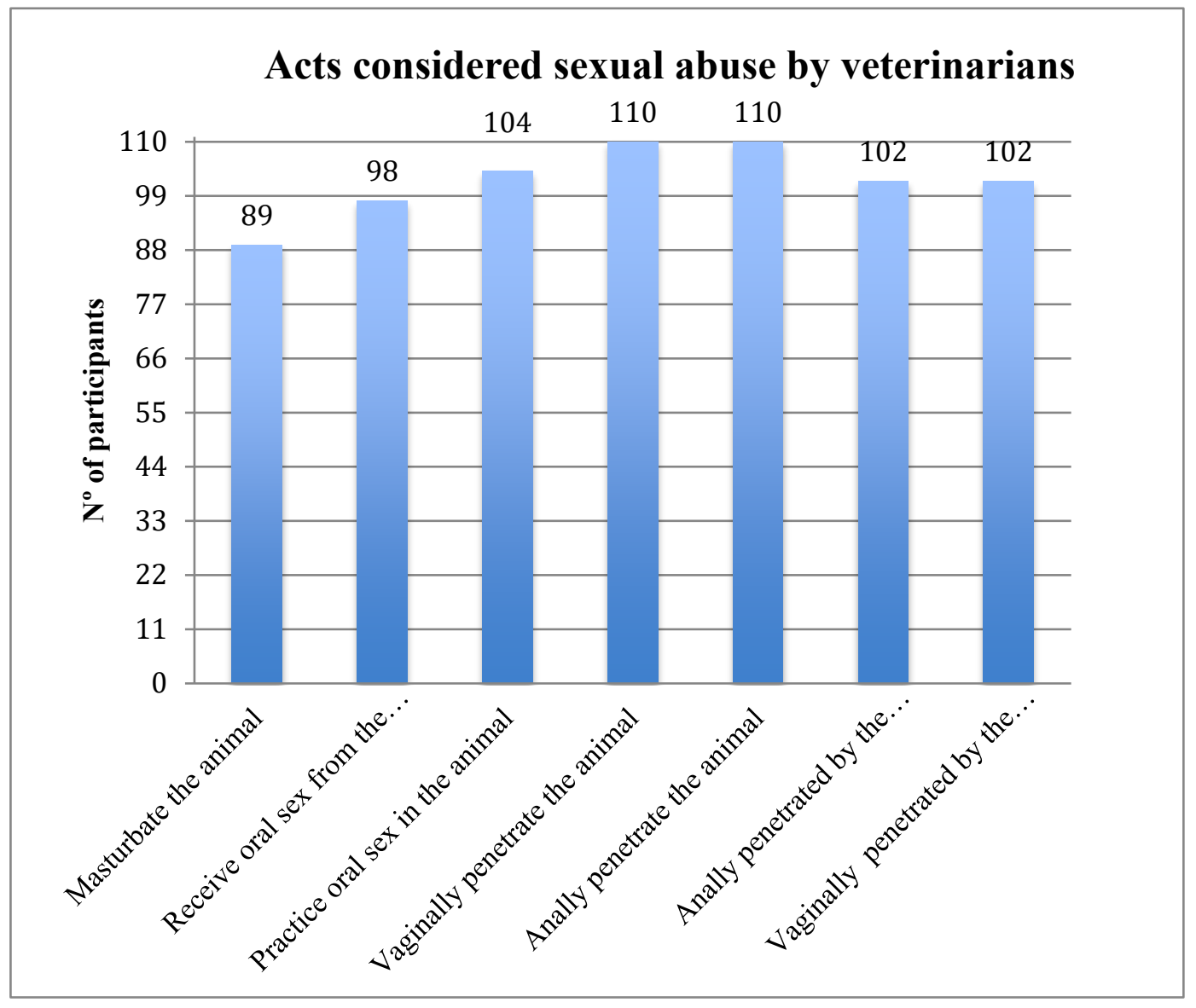

Figure 5 - Graphic representation of acts considered sexual abuse by veterinarians

The fact that some veterinary surgeons did not consider acts related to masturbation and oral-genital contact as an abuse may be justified with the opinion of Stettner (1990) who believes those kinds of acts, as well as frottage, are not an issue for animal protection. On the other hand, intercourse can be an abuse, depending on the size of the animal and the degree of force used ${ }^{148}$.

A possible explanation for the lower percentage of veterinarians considering masturbation as a sexual abuse $(80.9 \%)$ may be related to the fact that masturbation is often used for medical-assisted reproduction ${ }^{149}$ 150 .

A closer look at the previous studies reveals that masturbation is one of the most frequent behaviours reported by zoophiles. Performing oral stimulation on the animal is also a frequent practice made by zoophiles $^{151}$. Besides the fact that there are probably no physical injuries on the animal when those acts are performed, we strongly believe that they are a type of sexual abuse, as the majority of the participants in our study do. Indeed, as stated by many authors, similarly to sexual contact with children, it is impossible to obtain consent from the animal ${ }^{152} 153154$.

In fact, zoophilia based on mutual consent can only ever be speculation because it is impossible for the animal to speak for themself. Furthermore, we believe that animals could be sexually imprinted to like

\footnotetext{
${ }^{148}$ STETTNER, M. Unzucht mit Tieren—ein Tierschutzproblem. Deutsche Tierärztliche Wochenschrift, 97 (1990) $137-192$.

149 THOMASSEN, R. FARSTAD, W. Artificial insemination in canids: A useful tool in breeding and conservation. Theriogenology, 71 (2009) 190-199.

150 McDONNELL, S. M. GARCIA, M. C. KENNEY, R. M. Imipramine-Induced Erection, Masturbation, and Ejaculation in Male Horses. Pharmacology Biochemistry \& Behavior. 27 (1987) 187-191.

${ }^{151}$ BEETZ, A. Love, Violence and Sexuality in Relationships between Humans and Animals. Doctoral dissertation. (Germany 2002)

152 ASCIONE, F. R. (1993) Children who are cruel to animals: a review of research and sispimplications for developmental psychopathology. Anthrozoo"s. 6(4): istep:226-247.

${ }^{153}$ BEIRNE, P. Rethinking bestiality: Towards a concept of interspecies sexual assault. Theoretical Criminology 1/3 (1997) $317-$ 340.

${ }^{154}$ BIZAWU, K. RAMOS, A. O. B. NEPOMUCENO, G. L. Zoophilia in Brazil: A concrete case analysis and legal incrimination necessity. 12/01 (2017) 81-107.
} 
the sexual contact with a human ${ }^{155}$. Zoophiles believe their intimate relationship with animals are base on respect and trust and without violence, but it is a fact that even if no physical harm is inflicted on animals they are still used to sexually satisfy humans, functioning as mere sexual objects ${ }^{156}$.

However, almost all veterinarians in our study seem to agree about the consent question. When asked if they would consider one scenario an abuse even if the animal had showed no resistance to the act, $98.2 \%$ answered they would (Figure 6). Moreover, the majority of veterinary participants $(95.5 \%)$ agree that physical injuries do not have to exist for sexual contact to be considered sexual abuse (Figure 7).

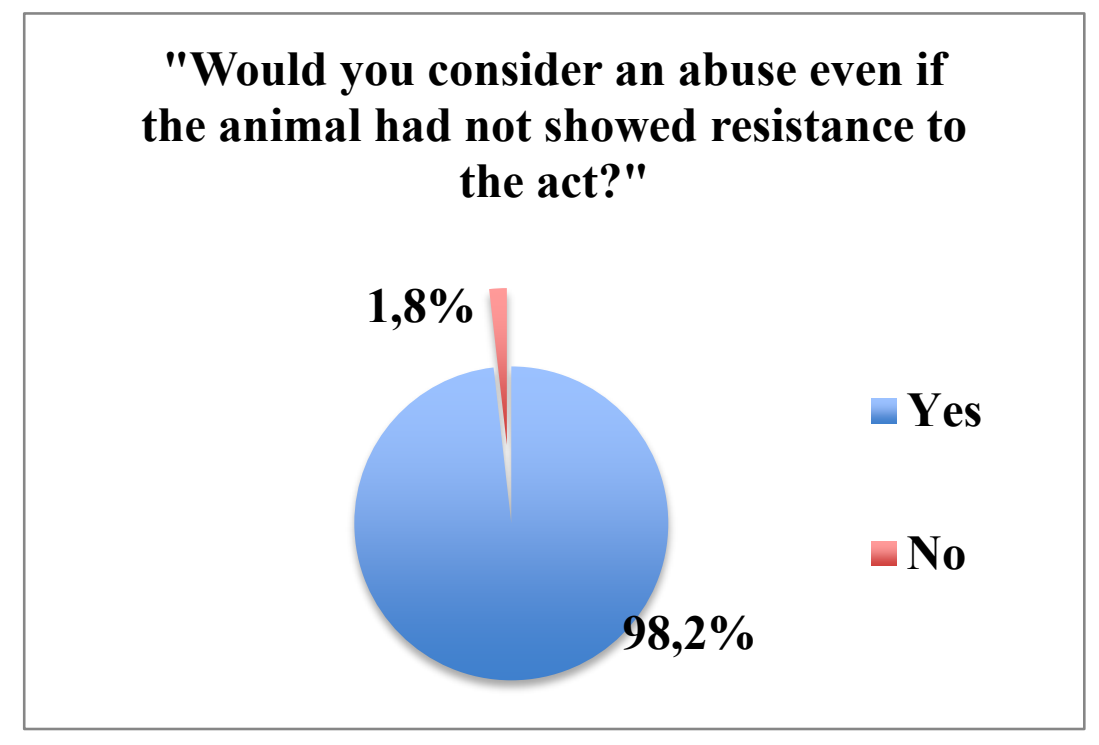

Figure 6 - Graphic representation of the answers to the question "Would you consider an abuse even if the animal had not showed resistance to the act?" (Results presented in percentage).

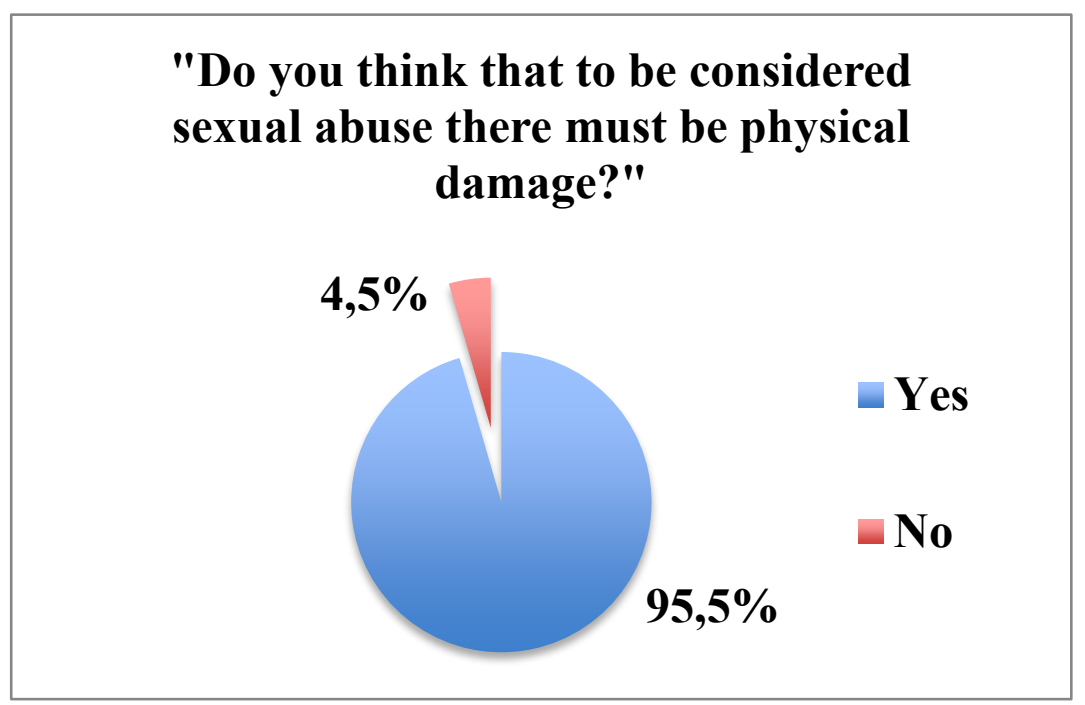

Figure 7 - Graphic representation of the answers to the question "Do you think that to be considered sexual abuse there must be physical damage?" (Results presented in percentage).

When asked "Do you consider that sexual abuse can cause psychological damages in the animal?" 93.7\% of participants answered they do. Furthermore, when testing the relation between the variable nationality and the answers to this question, we verified that it was statistically significant $(\mathrm{p}=0.048$ in Fisher's exact test). As you can see in Table 3, all Portuguese veterinarians considered that psychological damages could occur as a consequence of a sexual abuse towards an animal, while some Spanish veterinarians $(9.9 \%)$ considered it couldn't.

155 BEETZ, A. Bestiality and zoophilia: Associations with violence and sex offending. In Bestiality and Zoophilia - Sexual Relations with Animals. Purdue University Press (Indiana 2005) 46-70.

156 GOETSCHEL, A. F., BOLligER, G. AND GERRITSEN, V. (2005). Argumentarium Zoophilie, Zurich: www.tierimrecht.org/de/argumentarium/zoophilie.php. 
Table 2- Influence of nationality on the answer to the question "Do you consider that sexual abuse can cause psychological damages in the animal?" (Exact Fisher's test; Results expressed in percentages)

\begin{tabular}{llll} 
& No & Yes & P \\
\hline Portugal & $0 \%$ & $100 \%$ & \\
Spain & $9.9 \%$ & $90.1 \%$ & 0,048 \\
\hline
\end{tabular}

As far as we know, there is no reference in literature to sustain the view that animals may suffer psychological damages from sexual abuse. However, it has been proved that animals may suffer psychological damages due to traumatic episodes ${ }^{157} 158$.

Furthermore, the relation between the answers to the question above and considering masturbation a kind of sexual abuse was statistically significant ( $\mathrm{p}=0.047$ in Fisher's exact test). In fact, $60 \%$ of the veterinarians who believe that physical damages must occur to be considered a sexual abuse also considered that masturbation is not a sexual abuse.

\section{Pornography-seeking behaviour analysed with Google Trends}

\subsection{Portugal}

In order to determine the keywords associated with animal pornography in Portugal, the Internet program WordTracker was used. The three most used keywords determined by Wordtracker for Portugal were, in order, "zoofilia", "sexo com animais" and "porno com animais". Afterwards, with the help of Google trends we compared the popularity of those keywords as you can see in Figure 8. The keyword "zoofilia" is the most popular, second are the words "sexo com animais" and third "porno com animais".

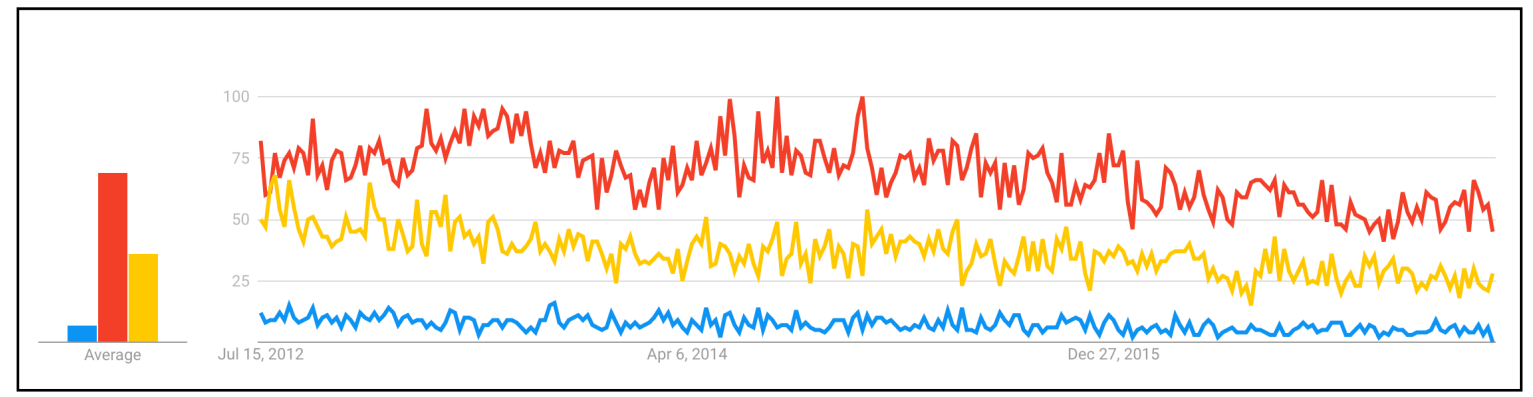

Figure 8 - Graphic representation of the keywords most searched in Portugal. In red: "zoofilia". In yellow: "sexo com animais. In blue: "porno com animais".

Subsequently, we analysed each keyword for the last five years in order to detect in which Portuguese districts those keywords were being searched for most. In order of the number of searches for the keyword "zoofilia" were the districts: Portalegre; Açores; Bragança; Évora and Beja (Figure 9).

\footnotetext{
${ }^{157}$ DURHAM, D. KIMWELE, C. KRANENDONK, G. OTALI, E. AKUGIZIBWE, T. MULCAHY, J. AJAROVA, L. JOHNSON, C. M. Signs of Mood and Anxiety Disorders in Chimpanzees. Journal Plous One (2011).

${ }^{158}$ DROBNY, S. MILLER, L. Inside the Mind of a Traumatized Dog: Does Canine PTSD exist, and if so, is it similar to PTSD in humans? (2016) Obtained from: http://u.osu.edu/drobny9hseportfolio/files/2016/07/DrobnySarah-CapstoneResearchPaper293xd04.pdf.
} 


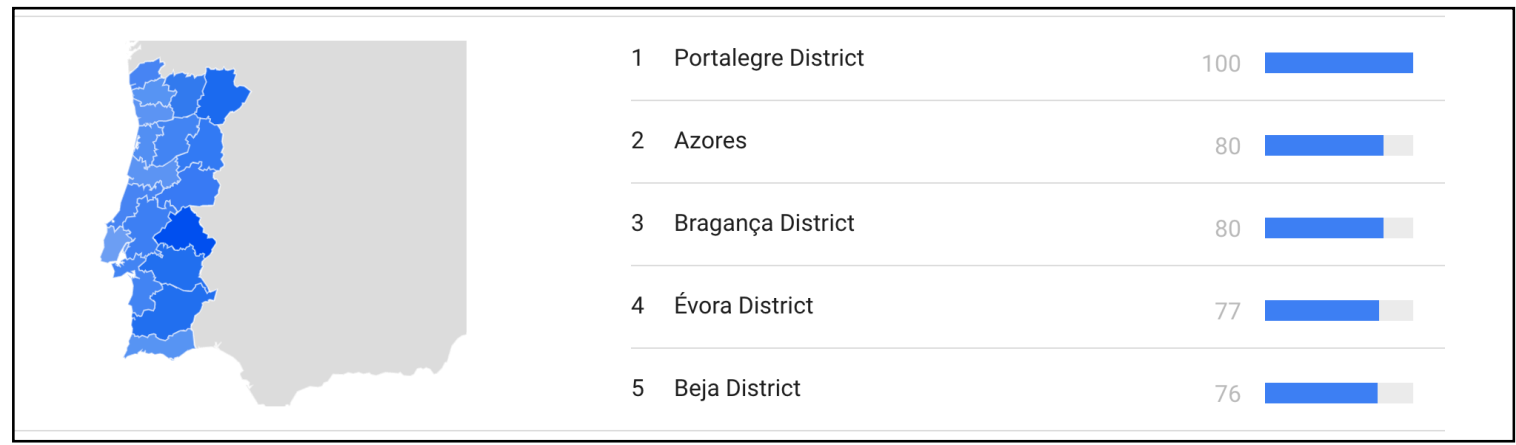

Figure 9 - Searches for the keyword "zoophilia" - distribution by district in Portugal.

The second most searched keyword phrase (Figure 8), "sexo com animais" had more searches in the districts (by order): Açores, Évora, Vila Real, Viseu and Santarém (Figure 10).

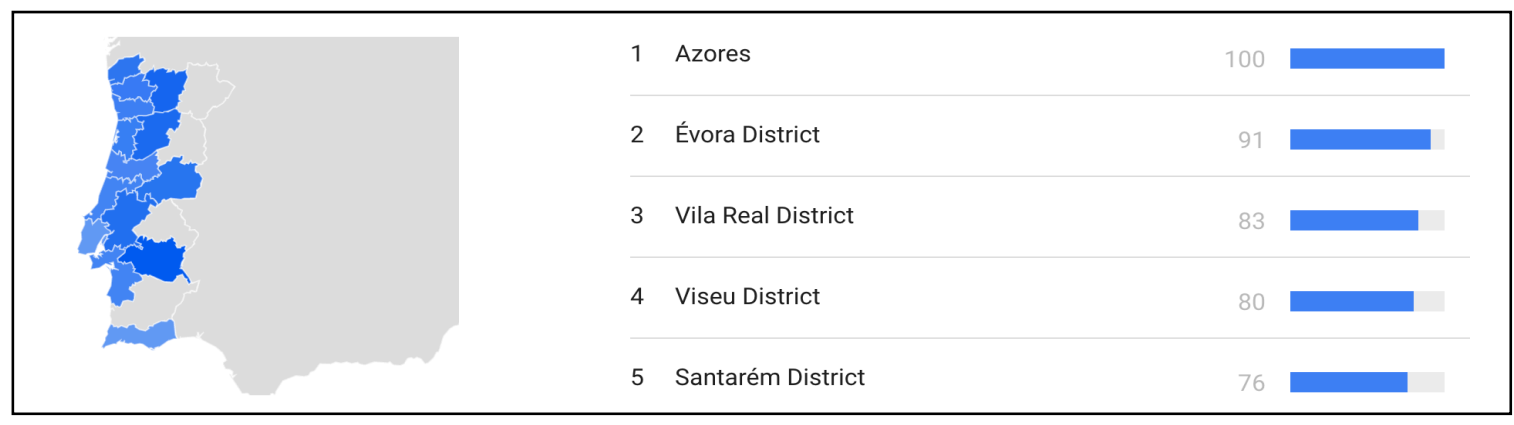

Figure 10 - Searches for the keyword "zoophilia" - distribution by district in Portugal.

Finally, we studied the searches for "porno com animais". There were searches for these keywords only in Lisbon and Porto district (Figure 11).

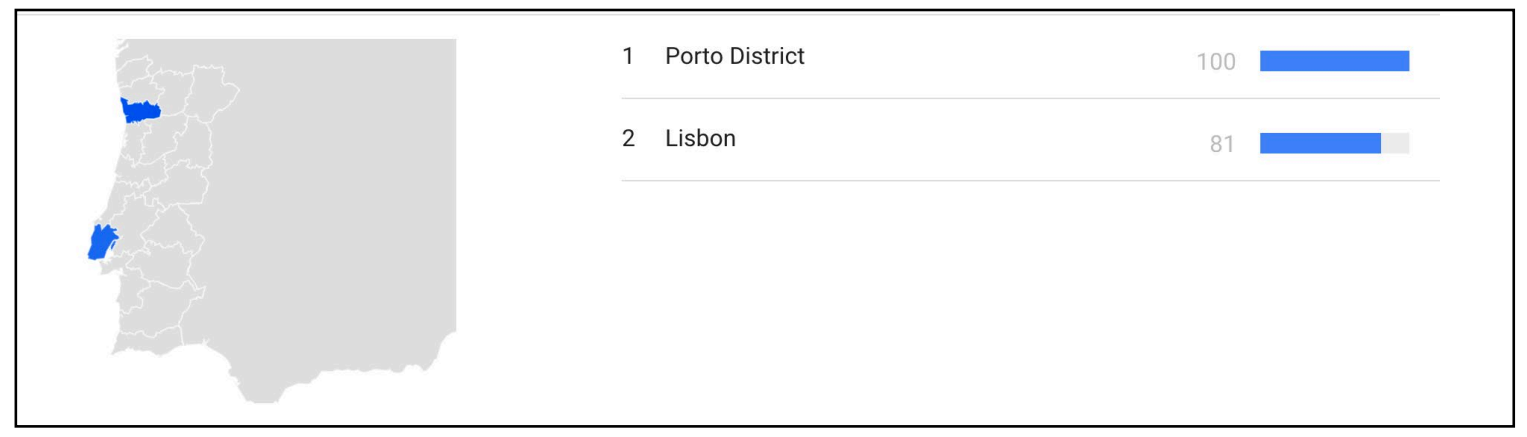

Figure 11 - Searches for the keyword phrase "porno com animais" - distribution by district in Portugal.

Contrary to what would be expected, in Portugal, a country with over 10 million residents, districts with a higher population were not the ones with more Internet searches for keywords associated to sexual contact with animals. Our results show quite the opposite, as in first place for the most searched keyword "zoofilia" comes Portalegre which has only 108.588 habitants. In second place is Açores $(245,283$ habitants), following Bragança, a district with only 109,409 inhabitants. The districts with more searches for the keywords "sexo com animais" (Figure 10) were Açores, Evora (156,207 inhabitants) and Vila Real $(87,941)$, also with less residents compared to districts like Lisbon $(2,821,349$ inhabitants) and Porto $(1,719,021$ habitants) the only two districts with searches for the keywords "porno com animais" as indicated by Wordtracker. However, as we can see in Figure 8, the searches for the words "porno com animais" were much less relevant compared to keywords "zoofilia" and "sexo com animais" in the past five years ${ }^{159}$.

${ }^{159}$ All data related to number of residents by district, was obtained on Instituto Nacional de Estatística, IP - Portugal for the year 2016. Available at: https://www.ine.pt/xportal/xmain?xpgid=ine_main\&xpid=INE. 


\subsection{Spain}

The keywords most searched for in Spain were, in order: "zoofilia", "porno con animales" and "sexo con animales (Figure 12). In contrast with Portugal, there is a huge difference in the searches for the top three keywords indicated by Wordtracker related to Spain.

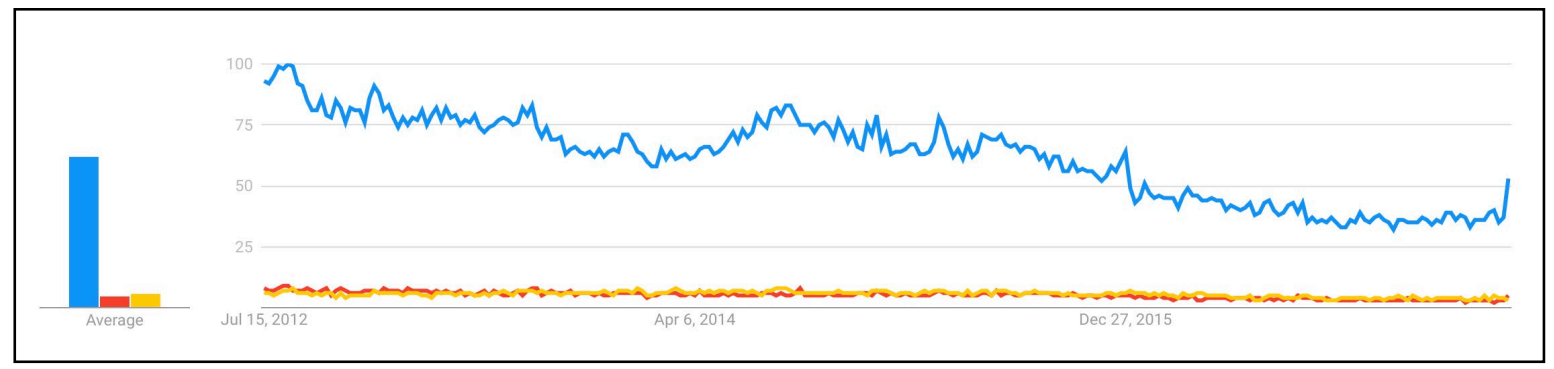

Figure 12 - Graphic representation of the keywords most searched in Portugal. In blue: "zoofilia". In yellow: "porno con animales". In red: "sexo con animales".

"Zoofilia", the keyword significantly searched for most in Spain, was most searched for in Extremadura, followed by Melilla and Andalusia (Figure 13).

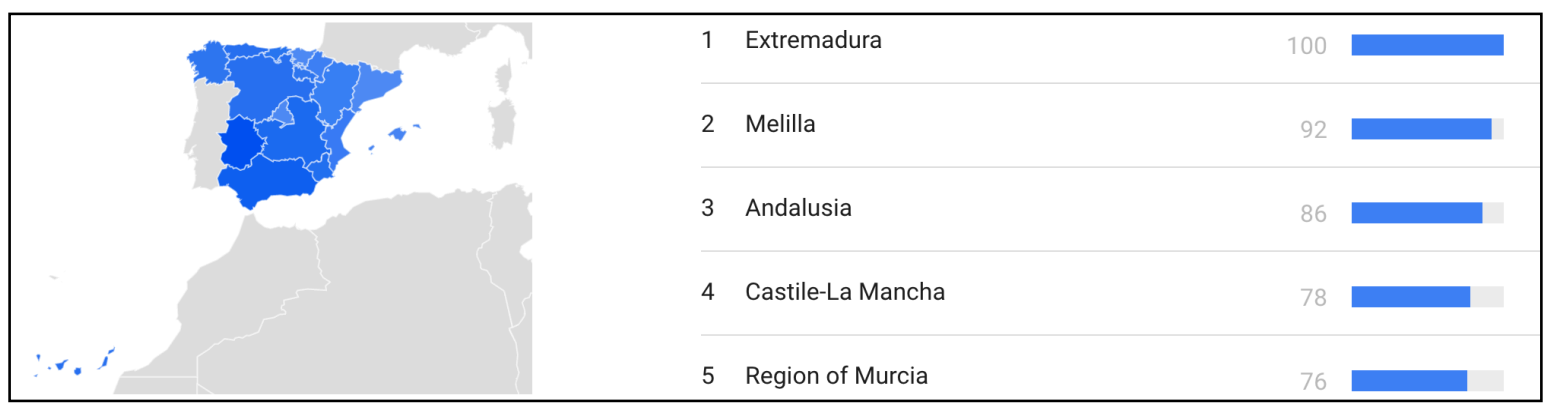

Figure 13 - Searches for the keyword "zoofilia" - distribution by district in Spain.

Although the keywords "porno con animales" and "sexo con animales" were significantly less searched for than the keyword zoophilia, we also analysed the regions where they were being searched for. As you can see on Figure 14, Extremadura also comes in first place regarding searches for "porno con animales" as well as for the keywords "sexo con animales" (Figure 15).

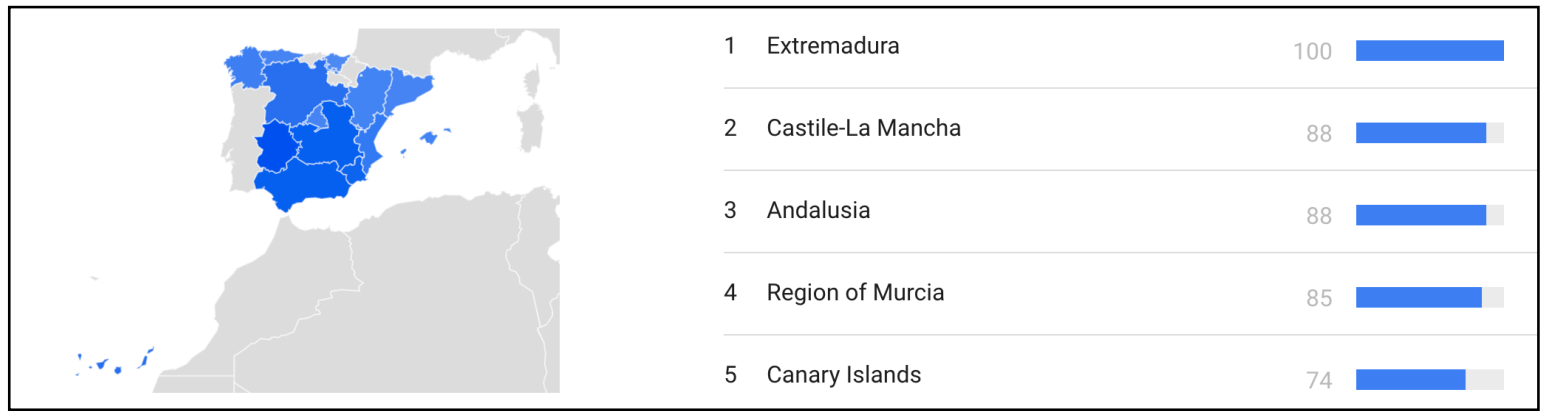

Figure 14 - Searches for the keywords "sexo con animales" - distribution by district in Spain.

\begin{tabular}{|lll|}
\hline & 1 Extremadura & 100 \\
& 2 Canary Islands & 87 \\
& 3 Andalusia & 87 \\
\hline
\end{tabular}

Figure 15 - Searches for the keywords "porno con animales" - distribution by district in Spain. 
A closer look at the data indicates, just as with Portugal, that the region which had more searches related to zoophilia was not the one with more inhabitants. Spain is estimated to have 46,815,916 residents and it was Extremadura, a region with only 1,104,499 residents, responsible for the most of those online searches. The seconde highest number of searches for the keyword "zoofilia" was in Melilla (Figure 13), a region with 81,323 inhabitants. However, in third place is the region with most people in Spain, Andalusia with 8,371,270 inhabitants. Other big autonomous regions like Madrid (6.421.874) and Catalunya (7.519.843 residents) were not included in the first five regions searching for any of the keywords selected by Wordtracker.

Although Google Trends does not supply the raw number of searches that occurred, the information it provides allows us to conclude which keywords were used more frequently in the past five years. It would be extremely difficult to know if people are actually searching for pornography with animals or if they are just interested in bestiality for research purposes. But clearly, with or without sexual intentions, people are interested and look for these words on Internet in both Portugal and Spain. Moreover, this kind of search may lead people to websites with animal pornography that promote violent acts and that offer animals for sexual purposes. However, they may also lead people to some valuable sites with information on the subject that should not be underestimated.

Unlikely child pornography, animal pornography is not considered a cybercrime. A cybercrime includes all crimes committed against information systems, computer data, or through the use of computer systems $^{160}$. Neither in Portugal nor in Spain is it illegal to access zoophilic content online. However, the fact that the Internet may allow the user to promote animal sexual abuse and disseminate crimes against animals should be taken into serious consideration by legislators and urges the criminalisation of such online content.

\section{VI- FINAL CONSIDERATIONS}

Animal sexual abuse is an alarmingly big problem in our society. The majority of cases have not been discovered and never will if most of the practices do not inflict injuries on the animal victims. In our opinion, all kinds of abuse should be considered a crime. Not only the physical injuries should be taken into account. As the majority of the veterinarians in our study agree, there is no need for physical injuries to exist to consider a sexual act with an animal as sexual abuse. Additionally, although there is no scientific evidence that psychological damages exist in these cases, the majority of veterinarians believe they may exist. Furthermore, it is impossible to prove that the animal has given their consent in such acts even if no resistance is shown.

Even if there is no clear evidence of a link between animal sexual abuse and other forms of abuse, some studies have pointed towards that connection. That said, veterinarians are in the front-line detecting cases of abuse, and by reporting them they are not only saving that victim but also other possible victims, human and non-human.

To the authors' knowledge, this is the first study to evaluate the incidence of cases of animal sexual abuse encountered by veterinarians in Portugal and Spain. The results of our survey leave no doubt that veterinarians in both countries encounter these cases.

The consensus view of veterinarians in our study seems to be that it should be mandatory to report these cases, and we strongly agree with their view if the there is immunity from civil and criminal liability for veterinarians that report such cases. Likewise, we believe it is crucial to create guidelines in both Portugal and Spain for practicing veterinarians, outlining how they should react when faced with cases of abuse, including sexual abuse. Several countries have developed these sorts of guidelines ${ }^{161} 162163$ to help veterinarians and Portugal and Spain would benefit in following those examples.

Furthermore, Internet searches reveal that people are looking for content related to this subject and our approach through Google trends reveals that there are some regions in these two countries where there is significantly more interest for this cyber content. However, a limitation in our study is that Google Trends

\footnotetext{
${ }^{160}$ Convention on Cybercrime, 23 November 2001, E.T.S. No. 185: criminalises illegal access, interception, data interference, system interference, and misuse of devices, among other forms of cyber operations that may negatively affect computer data or systems and criminalises content-related offences, including child pornography.

${ }^{161}$ ANIMAL FOLKS/ANIMAL LAW RESOURCES MN Reporting Animal Cruelty - role of veterinarian: establishing protocols to identify and report suspected animal cruelty in Minnesota (2017).

162 ARKOW, P. BOYDEN, P. PATTERSON-KANE, E. Practical Guidance for the Effective Response by Veterinarians to Suspected Animal Cruelty, Abuse and Neglect. American Veterinary Medical Association (2011).

163 Royal College of Veterinary Surgeons published a set of guidelines for practising veterinarians outlining how they should react when faced with a case of. See in:

http://www.rcvs.org.uk/advice-and-guidance/code-of-professional-conduct-for-veterinary-surgeons/supporting-guidance/

146 Derecho Animal. Forum of Animal Law Studies, vol. 10/4
} 
does not provide the exact number of times a term was searched for in a given time period. Such information would be useful in order to better understand exactly how many pornography searches occurred.

Further investigation needs to be done on sexual contact with animals. This is a subject where several areas need to be involved, such as veterinary medicine, anthrozoology, psychiatry and law. It seems that this subject is starting to become less taboo as more publications are available and the media is starting to cover more cases. The question of whether zoophilia is or is not a disease has caused much debate in psychiatry over the years, and some studies have tried to understand the reasons behind this sexual preference. However, the literature shows no consensus on the damages caused in the animal and more research focused on the victim (the animal) needs to be done.

Understanding sexual contact with animals is not by any means easy, but a first step is acknowledging that sexual abuse towards animals does not occur as infrequently as many people would like to believe. The literature shows that people have always engaged in sexual activities with animals and they still do so today.

We hope this study encourages many more on this subject, especially in the veterinary field, as we believe the evidence will show the abuse of animals to be much more widespread than currently accepted. Our study leaves no question about the existence of sexual abuse towards animals in Portugal and Spain besides the important limitation of the low response rate. A repeat study of a random sample of all veterinary practitioners in Portugal and Spain would increase the external validity of results and, as such, provide data more representative of the veterinary population.

All things considered, it seems reasonable to assume that zoophilia is a legitimate problem in Portugal and Spain and there is an urgency to adapt the legislation in order to defend the victims of this kind of abuse, who cannot speak for themselves.

\section{VII- REFERENCES}

1. Roban una oveja la violan y lo graban en video. La Razón. Retrieved from: http://www.larazon.es/historico/4605-roban-una-oveja-la-violan-y-lo-graban-en-videoJLLA_RAZON_299238 (2010).

2. Denmark pases law to ban bestiality. BBC newsbeat. Retrieved from: http://www.bbc.co.uk/newsbeat/article/32411241/denmark-passes-law-to-ban-bestiality (2015).

3. Snake sex video doctor found guilty. BBC News. Retrieved from: http://www.bbc.com/news/ukengland-london-37247160 (2016).

4. Suspeito de violar cadelas em Santarém. Correio da Manhã. Retrieved from: http://www.cmjornal.pt/portugal/detalhe/suspeito_de_violar_cadelas_em_santarem (2016).

5. Vê crianças violadas e sexo com animais. Correio da Manhã. Retreived from: http://www.cmjornal.pt/portugal/detalhe/20160326_2324_ve_criancas_violadas_e_sexo_com_ani mais (2016).

6. Florida dog owner, 23, accused of having sex more than 100 times with his pitbull named Baby Girl. Mail Online. Retrieved from: http://www.dailymail.co.uk/news/article-4118642/Manaccused-having-sex-100-times-pit-bull-named-Baby-Girl.html (2017).

7. ANIMAL FOLKS/ANIMAL LAW RESOURCES MN Reporting Animal Cruelty - role of veterinarian: establishing protocols to identify and report suspected animal cruelty in Minnesota (2017).

8. ABEL, G. G., BECKER, J.V., CUNNINGHAM-RATHNER, J., MITTLEMAN, M., ROULEAU, J. L. Multiple paraphilic diagnoses among sex offenders. Bull Am Acad Psychiat Law. 16/2 (1988) $153-168$.

9. ACOSTA-GUEVARA C, CALDERÓN-CARVAJALA, L. TORRESA, L. ROSSELLI, D. Cáncer de pene y sexo con animales: a propósito de un caso. Revista de Urolología Colombiana (2016).

10. AGGRAWAL, A. A new classification of zoophilia. Journal of Forensic and Legal Medicine 18 (2011) 73-78.

11. ALVAREZ, W. A. FREINHAR, J. P. A prevalence study of bestiality (zoophilia) in psychiatric inpatients, medical in-patients, and psychiatric staff. International Journal of Psychosomatics 38 (1991) 45-47.

12. APA. Diagnostic and Statistical Manual of Mental Disorders. 3rd edn. American Psychiatric Association (Washington DC 1980).

13. APA Diagnostic and Statistical Manual of Mental Disorders. 4th edn. (Washington D.C 1994).

14. APA Diagnostic and Statistical Manual of Mental Disorders. 5th edn. (Washington D.C 2013).

15. ARKOW P. The correlations between cruelty to animals and child abuse and istept the implications 
for veterinary medicine. Can Vet J. 33/8 (1992) 518-521.

16. ARKOW P. Child abuse, animal abuse, and the veterinarian. J Am Vet Med Assoc. 204/7 (1994) 1004-1007.

17. ARKOW, P. Recognizing and responding to cases of suspected animal cruelty, abuse, and neglect: what the veterinarian needs to know. Veterinary Medicine: Research and Reports: 6 (2015).

18. ARKOW, P. BOYDEN, P. PATTERSON-KANE, E. Practical Guidance for the Effective Response by Veterinarians to Suspected Animal Cruelty, Abuse and Neglect. American Veterinary Medical Association (2011).

19. ASCIONE, F. R. Children who are cruel to animals: a review of research and stepimplications for developmental psychopathology. Anthrozoo"s. 6/4 (1993) istepiz226-247.

20. BEERWORTH, A. A. "United states v. Stevens: a proposal for criminalizing crush videos under current free speech doctrine" Vermont Law Review. 35 (2001) 901

21.BEETZ, A. Love, Violence and Sexuality in Relationships between Humans and Animals. Doctoral dissertation. (Germany 2002).

22.BEETZ, A. Bestiality and zoophilia: Associations with violence and sex offending. In Bestiality and Zoophilia - Sexual Relations with Animals. Purdue University Press (Indiana 2005) 46-70.

23. BEIRNE, P. Rethinking bestiality: Towards a concept of interspecies sexual assault. Theoretical Criminology 1/3 (1997) 317-340.

24.BIZAWU, K. RAMOS, A. O. B. NEPOMUCENO, G. L. Zoophilia in Brazil: A concrete case analysis and legal incrimination necessity. 12/01 (2017) 81-107.

25.BLEVINS, R.O. A case of severe anal injury in an adolescent male due to bestial sexual experimentation. J Forensic Leg Med.16 (2009) 403-406.

26. BRADLEY N, RASILE K. Recognition \& management of animal sexual abuse. Clinicians Brief (2014) 73-75.

27. Canadian Veterinary Medical Association. Animal Abuse Position Statement (2011) Retrieved from: http://www.canadianveterinarians.net/documents/animal-abuse.

28. CHOI, H. VARIAN, H. Predicting the present with google trends. Econ Record 88 (2012) 2-9.

29. COLLEGI OFICIAL DE VETERINARIS DE BARCELONA Normes deontològiques comuns a la professió veterinaria catalane (2002). Obtained from: http://www.covb.cat/pdf/normes_deontologiques.pdf.

30.CORBACHO, J. M. R. Comentario en relación al maltrato de animales en la nueva reforma del código penal Español (LO 1/2015. Derecho animal - la webcenter de los animales con derecho. (2015) Obtained from: http://www.derechoanimal.info/images/pdf/Corbacho-Reforma.pdf.

31. CORBACHO, J. M. R. Nuevos tiempos para el delito de maltrato de animales a la luz de la reforma del código penal español (LO 1/2015). Revista Electrónica de Ciencia Penal y Criminología (2016) 18-16.

32.DEKKERS, M. Dearest Pet: On Bestiality. 2nd ed. (New York 1994).

33.DILLMAN, D., SMYTH, J.D. AND CHRISTIAN, L.M. Internet, Mail and Mixed-Mode Surveys. The Tailored Design Method, John Wiley \& Sons Inc., Prince Edward Island, (Canada 2009).

34.DONOFRIO, R. Human/animal sexual contact: A descriptive-exploratory study. Doctoral dissertation. The Institute for Advanced Study of Human Sexuality (San Francisco 1996).

35.DUARTE, M. L. GOMES, C. A. Animais: Deveres e Direitos. Instituto de Ciências JúridoPolíticas (2015).

36.DUFFIELD, G. HASSIOTIS, A. VIZARD, E. Zoophilia in young sexual abusers. J Forensic Psychiatry. 9 (1998) 294-304.

37.DURHAM, D. KIMWELE, C. KRANENDONK, G. OTALI, E. AKUGIZIBWE, T. MULCAHY, J. AJAROVA, L. JOHNSON, C. M. Signs of Mood and Anxiety Disorders in Chimpanzees. Journal Plous One (2011).

38.DROBNY, S. MILLER, L. Inside the Mind of a Traumatized Dog: Does Canine PTSD exist, and if so, is it similar to PTSD in humans? (2016) Obtained from: http://u.osu.edu/drobny9hseportfolio/files/2016/07/DrobnySarah-CapstoneResearchPaper293xd04.pdf.

39. ENGLISH, K. JONES, L. PATRICK, D. Sexual offender containment: use of post conviction polygraph. Ann NY Acad Sci. 989 (2003) 411-427.

40. ENNS, A. MVMA Public Awareness and Attitude Survey, Final Report. Winnipeg: Enrg Research Group, Manitoba Veterinary Medical Association (2006).

41.FLEMIN, W. M. JORI, B. BURTON, D. L. Characteristics of juvenile offenders admitting to sexual activity with nonhuman animals. Society and Animals.10 (2002) 31-45. 
42. GERDIN, J. A., MCFONOUGH, S. P. Forensic pathology of companion animal abuse and neglect. Vet Path Online. 50/6 (2013) 994-1006.

43. BOLLIGER, G. GOETSCHEL, A. F. Sexual relations with animals (zoophilia): An unrecognized problemisepin animal welfare legislation. In Bestiality and Zoophilia - Sexual Relations with Animals. Purdue University Press (Indiana 2005) 23-45

44. HELLMAN, D. S., BLACKMAN, N. Enuresis, firesetting and cruelty to animals: a triad predictive of adult crime. American Journal of Psychiatry 122 (1966) 1431-1435.

45.HENSLEY, C., TALLICHET, S.E. \& SINGER, S.D. Exploring the possible link between childhood and adolescent bestiality and interpersonal violence. Journal of Interpersonal Violence, 21 (2006) 910-923.

46.HENSLEY, C., TALLICHET, S.E. \& DUTKIEWICZ, E. L. Childhood bestiality: A potential precursor to adult interpersonal violence. Journal of Interpersonal Violence 25 (2010) 557- 567.

47.HVODZÍK BUGARSKY', A. KOTTFEROVA', J. VARGOVA', M. ONDRASOVICOVA',O. ONDRASOVIC, M, SASA'KOVA, N. Ethological, psychological and legal aspects of animal sexual abuse. The Veterinary Journal 172 (2006) 374-376

48.HUNT, M. Sexual Behavior in the 1970s. (New York 1974).

49.INSTUTO NACIONAL DE ESTATÍSTICA. See in: https://www.ine.pt/xportal/xmain?xpgid=ine_main\&xpid=INE.

50. KINSEY, A. C., POMEROY, W. B. and MARTIN, C. E. Sexual Behavior in the Human Male. Saunders Company. (Philadelphia 1948).

51.KINSEY, A. C., POMEROY, W. B. and MARTIN, C. E. and GEBHARD, P. H. Sexual Behavior in the Human Female. Saunders Company. (Philadelphia 1953).

52.KIROV G.K, LOSANOFF, J.E, KJOSSEV K. Zoophilia: a rare cause of traumatic injury to the rectum. Int J Care Injured. 33 (2002) 367-368.

53.KOGAN, L. R. SCHOENFELD-TACHER, R. M. PHD, PETER W. HELLYER, P. W. RISHNIW, M. RUCH-GALLIE, R. A. Survey of attitudes toward and experiences with animal abuse encountersispein a convenience sample of US veterinarians. JAVMA. 250 (2017) 6.

54.LOCKWOOD, R., ARKOW, P. Animal Abuse and Interpersonal Violence: The Cruelty Connection and Its Implications for Veterinary Pathology. Veterinary Pathology 53/5 (2016) 910918.

55.MCNALLY R. J., LUCKASH B. M. Behavioral treatment of zoophilic exhibitionism. istepiJ Behav Ther Exp Psychiatry 22/4 (1991) 281-4.

56. MASSEN, J. Zoophilie. Die sexuelle Liebe zu Tieren. Pinto Press (Köln 1994).

57.MASTERS, R. E. L. Sex-Driven People. Sherbourne Press (Los Angeles 1966).

58. MARTÍNEZ, J. Imputado por maltrato animal tras praticar sexo co su perra. Lasprovincias.es (2012). Retrieved from: http://www.lasprovincias.es/v/20121030/sucesos/imputado-maltratoanimal-tras-20121030.html.

59.McDONNELL, S. M. GARCIA, M. C. KENNEY, R. M. Imipramine-Induced Erection, Masturbation, and Ejaculation in Male Horses. Pharmacology Biochemistry \& Behavior. 27 (1987) 187-191.

60.MCGUINNESS, G. ALLEN, M. JONES, B. R. Non-accidental injury in companion animals in the Republic of Ireland. Irish Veterinary Journal: 58/7 (2005)

61.MENDONÇA, H. C. Recognising sentience in the Portuguese civil code. Derecho animal - la webcenter de los animales con derecho. (2017) Obtained from: http://www.derechoanimal.info/images/pdf/SentiencePortugueseCodeR.pdf.

62.MERCK, M. D. (N.D) The veterinarian's role in animal abuse.

63. MERCK, M. D. Veterinary Forensics: Animal Cruelty Investigations. Blackwell Publishing (Australia 2007).

64. MILETSKI, H. Understanding Bestiality and Zoophilia. East West Publishing (Bethesda 2002).

65. MILETSKI, H. A history of bestiality. In Bestiality and Zoophilia - Sexual Relations with Animals. Purdue University Press (Indiana 2005) 1-22.

66. MILLER, K. S., KNUTSON, J. F. Reports of severe physical punishment and exposure to animal cruelty by inmates convicted of felonies and by university students. Child Abuse and Neglect 21/1 (1997) 59-82.

67. MONTCLAIR, R. Tails of bestiality. Black Book Magazine (1997).

68. MUNRO, H., THRUSFIELD, M. Battered pets: sexual abuse. Journal of Small Animal Practice 42 (2001) 333-337.

69. MUNRO, H. Animal sexual abuse: a veterinary taboo? The Veterinary Journal 172 (2006) 195- 
197.

70. MUNRO, R. MUNRO, H. M. (2008) Animal abuse and unlawful killing. Forensic Veterinary Pathology. Philadelphia: Saunders.

71. ORDEM DOS MÉDICOS VETERINÁRIOS Código Deontológico Médico-Veterinário (2009) Obtained from: https://www.omv.pt/estatuto-e-codigo-deontologico/codigo-deontologico.

72. ORGANIZACIÓN COLEGIAL VETERINARIA ESPAÑOLA Código Deontológico para el ejercício de la profesión veterinaria (2006) Obtained from: http://www.colvet.es/node/165

73. RODRÍGUEZ, N. La explotación sexual de animales en la Ley Orgánica 10/2015, de 30 de marzo, por la que se modifica el Código Penal español. Derecho animal - la webcenter de los animales con derecho. (2015) Obtained from www.derechoanimal.info/images/pdf/NML-Explotacionsexual-CP.pdf

74. ROPELATO, J. Internet pornography statistics. (2006). Retrieved from: http://internet-filterreview.toptenreviews.com/internet-pornography-statistics.html.

75. ROSENBERGER, J. R. Bestiality. Medco Books (Los Angeles 1968).

76.SALISBURY, J. E.. The Beast Within-Animals in the Middle Ages. (New York 1994)

77.SÁNCHEZ, A. Respuesta judicial ante el maltrato animal: analisis de la aplicación del articulo 337 del código penal. Centro de estudios jurídicos. (N.D.)

78.SCHENK, A. M. COOPER-LEHKI, C. KEELAN, C. M. FREMOUW, W. J. Underreporting of bestiality among juvenile sex offenders: Polygraph versus self-report. Journal of Forensic Sciences, 59 (2014) 540-542.

79. SEIGFRIED-SPELLAR, K.C., ROGER, M.K. Does deviant pornography use follow a guttmanlike progression? Computers in Human Behavior. 29 (2013) 1997-2003.

80.SEIGFRIED-SPELLAR, K.C. Deviant pornography use: The role of early-onset adult pornography use and individual differences. International Journal of Cyber Behavior, Psychology and Learning, 6/3 (2016) 34-47.

81.SINGG, S. Health Risks of Zoophilia/Bestiality. J Biol Med Science. 1/1 (2017).

82.STETTNER, M. Unzucht mit Tieren-ein Tierschutzproblem. Deutsche Tierärztliche Wochenschrift, 97 (1990) 137-192.

83.STERN A. W. SMITH-BLACKMORE, M. Veterinary Forensic Pathology of Animal Sexual Abuse. Veterinary Pathology

84. THOMASSEN, R. FARSTAD, W. Artificial insemination in canids: A useful tool in breeding and conservation. Theriogenology, 71 (2009) 190-199.

85. THIEL, D. A resource for veterinarians on recognizing and reporting animal abuse. Can Vet J, 43/2 (2002) 97-98.

86. TOMÁS, C. 14 processos crime por maus-tratos a animais, mas só dois no tribunal. (2015) Available at: http://expresso.sapo.pt/sociedade/2015-10-29-14-processos-crime-por-maus-tratos-aanimais-mas-so-dois-no-tribunal.

87.TULLENERS, E.P. RICHARDSON, D. W. REID, B.V. Vaginal evisceration of the small SE-

88. VOLLENHOVEN, E. V. SONNTAG, Q The Role of the Veterinarian in the Prosecution of Cases of Animal Abuse: Writing expert witness reports. (N.D)

89. WAINE, W. W. Canine Sexualis. Publisher's Export. (San Diego 1968).

90.WEIDNER, E.. Sodomie und Sadismus als Tierschutzproblem. Doctoral Dissertation. University of Giessen (Germany 1972).

91. WELLMAN, A. Woman 'filmed herself having sex with a sausage dog and then sent sick video to a pal'. Mirror. (2016) Retrieved from: http://www.mirror.co.uk/news/world-news/woman-filmedherself-having-sex-7632818.

92. WILLIAMS J. W. and WEINBERG M. S. Zoophilia in men: A study of sexual interest in animals. Archives of Sexual Behavior 32/6 (2003) 523-535.

93. WILliAMS, V. M. DALE, A. R. ClARKE, N. GARRETT, N. K. G. Animal abuse and family violence: Survey on the recognition of animal abuse by veterinarians in New Zealand and their understanding of the correlation between animal abuse and human violence. New Zealand Veterinary Journal, 56/1 (2008) 21-28.

94.WISCH, R. State animal sexual assault laws. (2017) is state-animal-sexual-assault-laws.

95. YAŞAR, A., YIĞIT, A. Zoophilia: An evaluation from perspective the holy religions, legislation and ethics. Eurasian Journal of Veterinary Sciences. 32/2 (2016) 114-119.

96.ZEQUI, S. C. et al. Sex with Animals (SWA): Behavioral Characteristics and Possible Association 
with Penile Cancer. A Multicenter Study. Journal of Sexual Medicine. 9/7 (2012) 1860-7 


\section{APENDIX 1 - Online survey: Spanish version}

\section{Cuestionario sobre el maltrato animal - destinado a médicos veterinarios en España}

El presente cuestionario servirá como herramienta de estudio para un Trabajo Final del Master en Derecho Animal y Sociedad de la Universidad Autónoma de Barcelona.

Pedimos la colaboración de veterinarios que trabajen en clínica de pequeños o grandes animales. Toda la información recogida en este cuestionario es anónima, confidencial y con fines exclusivamente académicos.

Este cuestionario se compone de algunas preguntas demográficas seguidas de 10 preguntas sobre el tema. Todas las preguntas son de opción múltiple a excepción de una.

Se tardará 5 minutos en responder al cuestionario.

*Obrigatório

Edad *

Selecionar

Género *

Selecionar

Año en el que se graduó *

Selecionar

Universidad en la que estudió *

Selecionar

¿Actualmente ejerce en el área de veterinaria clínica? *

Sí

No 
Tipo de práctica

Pequeños animales

Grandes animales

Mixta

Outra:

Más del $50 \%$ de sus pacientes son *

Pequeños animales

Animales de producción

Equinos

Outra:

¿Alguna vez ha sospechado que estaba ante un caso de maltrato animal o ha tenido la certeza de estarlo? *

Sí

No

¿Alguna vez ha denunciado un caso de maltrato?

Sí

No

¿Considera que debería ser obligatorio que los médicos veterinarios denuncien los casos de maltrato?
Sí
No

¿Alguna vez ha sospechado que estaba ante un caso en el que el animal hubiera sido víctima de abuso sexual? *

Sí

No 
¿Cuántos casos de certeza o de sospecha de abuso sexual ha presenciado?

Selecionar

Indicar cuáles son los motivos que le llevaron a sospechar o a estar seguro de que se trataba de abuso sexual:

\section{A sua resposta}

¿Cuáles de estos actos consideraría que constituyen abuso sexual? *

Masturbación del animal

Recibir sexo oral del animal

$\square$ Practicar sexo oral al animal

$\square$ Penetrar vía vaginal al animal

Penetrar vía anal al animal

$\square$ Recibir penetración anal del animal

$\square$ Recibir penetración vaginal del animal

¿Consideraría que se trata de un caso de abuso sexual incluso si el animal no muestra ningún tipo de resistencia al acto? *

Sí

No

¿Considera que para que exista abuso sexual tiene que producirse daño físico al animal? *

Sí

No

¿Cree que un animal abusado sexualmente puede tener daños psicológicos como consecuencia? *

sí

$\bigcirc$ No 